\title{
Effect of magnesium substitution on structural and dielectric properties of $\mathrm{LiNiPO}_{4}$
}

\author{
K. ANAND ${ }^{1}$, B. RAmAmurthy ${ }^{1}$, V. VeERAiAh ${ }^{2}$, K. ViJAYA BABU $^{3, *}$ \\ ${ }^{1}$ Department of Instrumentation and USIC, Sri Krishnadevaraya University, Anantapur, India \\ ${ }^{2}$ Department of Physics, Andhra University, Visakhapatnam, India \\ ${ }^{3}$ Advanced Analytical Laboratory, Andhra University, Visakhapatnam, India
}

\begin{abstract}
The aim of this paper is to study the effect of $\mathrm{Mg}^{2+}$ doping in place of $\mathrm{Ni}$ in $\mathrm{LiNiPO}_{4}$ compounds synthesized by solid state reaction method. As $\mathrm{Mg}$ is a relatively light and cheap, and is expected to stabilize the structure, it has been considered as a substituent for $\mathrm{Ni}$. The structural and conductivity studies of the substituted phases are discussed in comparison with $\mathrm{LiNiPO}_{4}$. In this study, we have proposed cation-substituted compounds, $\mathrm{LiNi}_{1-\mathrm{x}} \mathrm{Mg}_{\mathrm{x}} \mathrm{PO}_{4}(\mathrm{x}=0,0.05,0.1$ and 0.15$)$ where a part of the divalent state of $\mathrm{Ni}^{2+}$ is replaced with the corresponding amount of $\mathrm{Mg}^{2+}$ and where the charge compensation is maintained by lithium deficiency. It is possible to obtain the mentioned compounds because the pristine $\mathrm{LiNiPO}_{4}$ compound is stable in ambient atmosphere, which differs considerably from the $\mathrm{LiCoPO}_{4}$ compound.
\end{abstract}

Keywords: cathode materials; XRD; FT-IR; modulus analysis

(C) Wroclaw University of Science and Technology.

\section{Introduction}

Energy is a fundamental component in the daily lives of human society, and it can be used in different forms in our day-to-day activities. In recent years, energy demand has increased due to high energy consumption in different fields such as industry, transportation and household [1-4]. In this context, lithium-ion battery technology currently plays an important role in producing alternative energy storage devices, because of its inherent outstanding characteristics [5-8]. The technology offers the greatest development potential for automobile industry, particularly for electric vehicles (EV) and hybrid electric vehicles (HEV), which substitute electricity for a portion of petroleum used to power the vehicles. One of the challenges for improving the performance of lithium ion batteries to meet the demanding requirements for energy storage is the development of suitable cathode materials. Cathode materials must be able to accept lithium ions repeatedly (for recharging) and release

*E-mail: vijayababu.k@gmail.com lithium ions quickly (for high current). Transition metal oxides based on spinel and olivine structures have been shown to be promising but improvements are needed to reduce their cost and extend effective lifetime [9-11]. Particularly, olivine structured materials $\left(\mathrm{LiMPO}_{4}\right)$ are expected to bring an improvement in cycling stability and enhance the power due to the reduction of the lithium-ion diffusion length. The performance of cathode materials can be improved by doping, but the interpretation of doping effects can be complicated due to the interrelations between doping, microstructure and morphology, since the microstructure formed can be affected by the dopant addition [12-15].

This paper deals with the synthesis and characterization of $\mathrm{LiNi}_{1-\mathrm{x}} \mathrm{Mg}_{\mathrm{x}} \mathrm{PO}_{4}(\mathrm{x}=$ 0, 0.05, 0.1 and $0.15)$ obtained by solid state reaction method. The materials were characterized for phase purity and cation environment by X-ray diffraction. Fourier transform infrared (FT-IR) spectroscopy was used to study the local order. Electrical properties were studied by impedance spectroscopy. The structural and conductivity studies of the substituted phases were discussed in comparison with $\mathrm{LiNiPO}_{4}$. 


\section{Experimental}

The cathode compositions were synthesized by a solid-state reaction method from stoichiometric amounts of $\mathrm{Li}_{2} \mathrm{CO}_{3}$ (Merck $99.9 \%$ ), $\mathrm{NiO}$ (Merck $99.9 \%), \mathrm{MgO}$ (Merck $99.9 \%$ ) and $\left(\mathrm{NH}_{4}\right)_{3} \mathrm{PO}_{4}$ (Merck $99.9 \%$ ). The solid state reaction synthesis method involved three steps. First, the precursors, as raw materials, were well mixed and thoroughly ground, then subjected to heat treatment at a temperature of $120{ }^{\circ} \mathrm{C}$ for 12 hours and $500{ }^{\circ} \mathrm{C}$ for 4 hours to obtain the samples free of gases. Finally, the mixture was reground and sintered at a temperature of $850{ }^{\circ} \mathrm{C}$ for 20 hours to complete the chemical reaction.

The powder X-ray diffraction (XRD) data of the sample was collected on a Rigaku $\mathrm{CuK} \alpha$ diffractometer with diffraction angles of $10^{\circ}$ to $50^{\circ}$ in increments of $0.02^{\circ}$. The unit cell lattice parameter was obtained by the unit cell software from the $2 \theta$ and (h k l) values. The particle morphology of the powders was observed using field effect scanning electron microscopy images taken from Carl Zeiss, EVOMA 15, Oxford Instruments, Inca Penta FETx3.JPG. Fourier transform infrared (FT-IR) spectra were obtained on a Shimadzu FT-IR-8900 spectrometer using $\mathrm{KBr}$ pellet technique in the wave number range between $400 \mathrm{~cm}^{-1}$ and $1300 \mathrm{~cm}^{-1}$. The impedance study was performed by a Hioki 3532-50 LCR Hitester in the frequency range of $50 \mathrm{~Hz}$ to $5 \mathrm{MHz}$ at the temperature range from room temperature to $150{ }^{\circ} \mathrm{C}$.

\subsection{X-ray diffraction}

The X-ray diffraction was used to obtain information about the structure, composition and the state of polycrystalline materials. Fig. 1 shows the $\mathrm{X}$-ray diffraction patterns of the $\mathrm{LiNi}_{1-\mathrm{x}} \mathrm{Mg}_{\mathrm{x}} \mathrm{PO}_{4}$ $(\mathrm{x}=0,0.05,0.1$ and 0.15$)$ cathode materials synthesized by solid state reaction method. It was found that all the peaks could be indexed to a single phase of ordered olivine type structure belonging to orthorhombic Pnma space group. No peaks related to alternative phases have been detected in the pattern. Thus, it can be concluded that the series of high purity $\mathrm{LiNi}_{1-\mathrm{x}} \mathrm{Mg}_{\mathrm{x}} \mathrm{PO}_{4}(\mathrm{x}=0,0.05,0.1$ and $0.15)$ cathode materials was synthesized from the
$\mathrm{LiNiPO}_{4}$ material described previously. Similar to the pure $\mathrm{LiNiPO}_{4}$, in the doped $\mathrm{LiNi}_{1-\mathrm{x}} \mathrm{Mg}_{\mathrm{x}} \mathrm{PO}_{4}$ $(\mathrm{x}=0,0.05,0.1$, and 0.15$)$ samples, the transition metal ion still occupied the octahedral $\mathrm{M}^{2+}$ site homogeneously, in a ratio determined by the precursor material. All diffraction peaks are sharp and distinguishable [16-18].

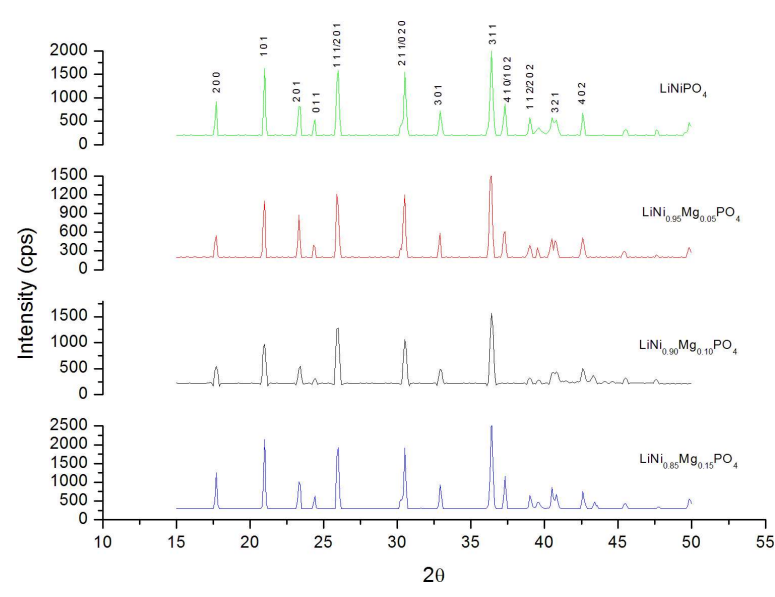

Fig. 1. XRD spectra of $\mathrm{LiNi}_{1-\mathrm{x}} \mathrm{Mg}_{\mathrm{x}} \mathrm{PO}_{4}(\mathrm{x}=0,0.05$, 0.1 and 0.15 ).

Based on the XRD graphs, lattice parameters for prepared compounds were calculated using Unit cell (1991) software and summarized in Table 1. A linear correlation between lattice parameters and the content of magnesium in the composition has been found. Lattice parameters a and b decreased linearly with the increasing ratio of magnesium due to the smaller Shannon radii of $\mathrm{Ni}$ $(0.69 \AA)$ compared to $\mathrm{Mg}(0.71 \AA)$. The lattice parameter $\mathrm{c}$ remained unchanged. For the magnesium doped $\mathrm{LiNi}_{1-\mathrm{x}} \mathrm{Mg}_{\mathrm{x}} \mathrm{PO}_{4}(\mathrm{x}=0,0.05,0.1$ and 0.15$)$ cathode materials, lattice parameters $\mathrm{a}$ and $\mathrm{b}$ are slightly larger than those of pure $\mathrm{LiNiPO}_{4}$ sample with the same composition [19-22].

\subsection{SEM with EDS}

The powder morphology of the samples at different magnifications was determined for a series of olivine structures of $\mathrm{LiNi}_{1-\mathrm{x}} \mathrm{Mg}_{\mathrm{x}} \mathrm{PO}_{4}(\mathrm{x}=0$, $0.05,0.1$ and 0.15$)$ prepared by solid-state reaction method. As shown in Fig. 2, the powder samples exhibit relatively uniform grain size distribution, revealing the well-developed crystallinity, 
Table 1. Lattice parameters, space group and cell volume for different compounds.

\begin{tabular}{lccccc}
\hline \multicolumn{1}{c}{ Compound } & $\mathrm{a}[\AA]$ & $\mathrm{b}[\AA]$ & $\mathrm{c}[\AA]$ & Space group & Cell volume $[\AA]^{3}$ \\
\hline \hline $\mathrm{LiNiPO}_{4}$ & 10.0345 & 5.8524 & 4.6629 & Pnma & 273.8411 \\
$\mathrm{LiNi}_{0.95} \mathrm{Mg}_{0.05} \mathrm{PO}_{4}$ & 10.0341 & 5.8762 & 4.6669 & Pnma & 275.1785 \\
$\mathrm{LiNi}_{0.90} \mathrm{Mg}_{0.10} \mathrm{PO}_{4}$ & 10.0533 & 5.8561 & 4.6554 & Pnma & 274.0853 \\
$\mathrm{LiNi}_{0.85} \mathrm{Mg}_{0.15} \mathrm{PO}_{4}$ & 10.0401 & 5.8598 & 4.6682 & Pnma & 275.1785 \\
\hline
\end{tabular}

confirmed also by the XRD patterns. In addition, the synthesized samples exhibit porous structure, which facilitates faster penetration of the electrolyte through the cathode material.

However, some exceptionally large particles are observed in addition to the smaller ones. From the grain size, morphological changes resulting from the variation of the composition of the substituted cations $\mathrm{Li}$ and $\mathrm{Mg}$ in the samples are clearly seen [23-25]. The average grain size is in the range of $10 \mu \mathrm{m}$ for all samples. It has also been revealed that when the amount of substituted Mg increases, the grain size decreases, which is consistent with the crystallinity nature observed by XRD.

The compositional homogeneity of nickel, magnesium, oxygen and phosphorous has been examined by EDS. As shown in Fig. 3, there are no other impurity peaks in the spectra besides $\mathrm{Ni}$, $\mathrm{P}, \mathrm{Mg}$ and $\mathrm{O}$. Since the titration of the light element lithium is difficult with this spectroscopic technique, it was not possible to assess the lithium content.

\subsection{FT-IR}

Fig. 4 shows the FT-IR spectra of the $\mathrm{LiNi}_{1-\mathrm{x}} \mathrm{Mg}_{\mathrm{x}} \mathrm{PO}_{4}(\mathrm{x}=0,0.05,0.1$ and 0.15$)$ compounds.

From the Fourier transform study, we observe that the fundamental frequencies of $\mathrm{PO}_{4}$ polyanions are split due to the correlation effect which, in turn, is induced by the coupling of $\mathrm{M}-\mathrm{O}$ bonds. As a result, the vibrational spectra of $\mathrm{LiNi}_{1-\mathrm{x}} \mathrm{Mg}_{\mathrm{x}} \mathrm{PO}_{4}$ $(\mathrm{x}=0,0.05,0.1$ and 0.15$)$ are dominated by the fundamental vibrations of $\mathrm{PO}_{4}$ polyanions, which is not unusual. Fig. 4 shows four fundamental vibrations of $\mathrm{PO}_{4}$, such as stretching mode around $v_{1}: 940 \mathrm{~cm}^{-1}$, a doublet at around $v_{2}: 525 \mathrm{~cm}^{-1}$ and two triplets viz., $v_{3}$ and $v_{4}$ in the region of $1059 \mathrm{~cm}^{-1}$ to $1102 \mathrm{~cm}^{-1}$ and at $732 \mathrm{~cm}^{-1}$. Further, the peaks observed at the $547 \mathrm{~cm}^{-1}$ and $580 \mathrm{~cm}^{-1}$ region are attributed to the asymmetric stretching modes of $\mathrm{NiO}_{6}$ octahedra, thus, confirming the formation of $\mathrm{LiNi}_{1-\mathrm{x}} \mathrm{Mg}_{\mathrm{x}} \mathrm{PO}_{4}(\mathrm{x}=0,0.05,0.1$ and $0.15)$. Basically, $v_{1}$ and $v_{3}$ modes involve the symmetric and antisymmetric stretching vibration of the $\mathrm{P}-\mathrm{O}$ bonds, where as $v_{2}$ and $v_{4}$ modes involve mainly $\mathrm{O}-\mathrm{P}-\mathrm{O}$ symmetric and antisymmetric bending modes with a small contribution of $\mathrm{P}$ vibration [26]. The vibrational modes and band assignments in $\mathrm{LiNi}_{1-\mathrm{x}} \mathrm{Mg}_{\mathrm{x}} \mathrm{PO}_{4}(\mathrm{x}=$ 0, 0.05, 0.1 and $0.15)$ are presented in Table 2.

\subsection{Impedance analysis}

The complex impedance spectroscopy (CIS), sometimes called AC impedance spectroscopy, is a useful characterization technique for investigating the electrical properties of materials. Moreover, the CIS measurement technique is also useful to investigate the temperature and frequency dependent behavior of AC conductivity and dielectric constant. The results obtained from these analyses can provide information about the electrical behavior of the samples $[27,28]$. In the present study, the electrical properties of $\mathrm{LiNi}_{1-\mathrm{x}} \mathrm{Mg}_{\mathrm{x}} \mathrm{PO}_{4}(\mathrm{x}=0,0.05$, 0.1 and 0.15 ) compounds were studied in the temperature range of $30{ }^{\circ} \mathrm{C}$ to $150{ }^{\circ} \mathrm{C}$ in the frequency range of $50 \mathrm{~Hz}$ to $5 \mathrm{MHz}$. The measured impedance data can be represented in different forms, using the inter relations as follows:

- complex impedance $Z^{*}=Z^{\prime}-j Z^{\prime \prime}$, - complex modulus $\mathrm{M}^{*}=\mathrm{M}^{\prime}+\mathrm{j} \mathrm{M}^{\prime \prime}=\mathrm{j} \omega \mathrm{C}_{0} \mathrm{Z}^{*}$, - complex permittivity $\varepsilon^{*}=\varepsilon^{\prime}-\mathrm{j} \varepsilon^{\prime \prime}$

where $\mathrm{j}=\sqrt{-1}, \mathrm{C}_{0}$ is the vacuum capacitance and $\omega=2 \pi f$ is the angular frequency. $\left(Z^{\prime}, M^{\prime}, \varepsilon^{\prime}\right)$ and $\left(\mathrm{Z}^{\prime \prime}, \mathrm{M}^{\prime \prime}, \varepsilon^{\prime \prime}\right)$ are the real and imaginary components of impedance, modulus and permittivity. 


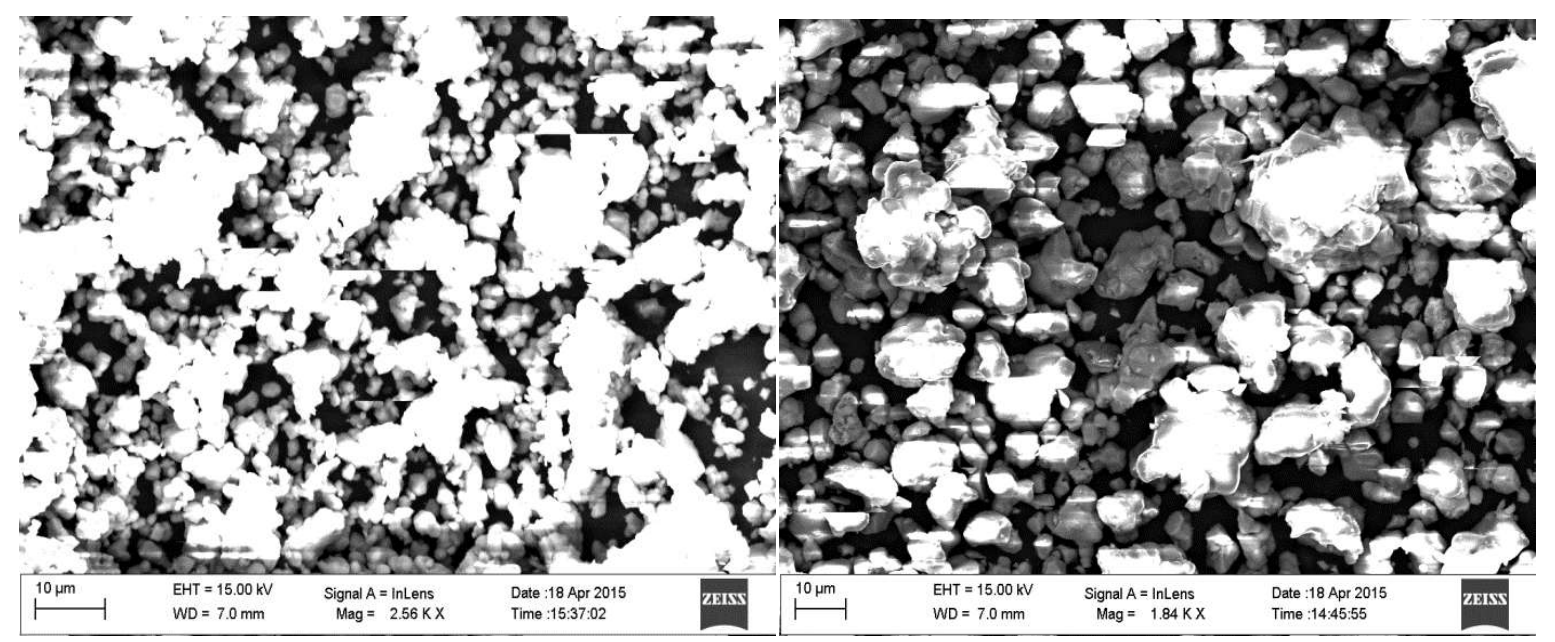

(a)

(b)

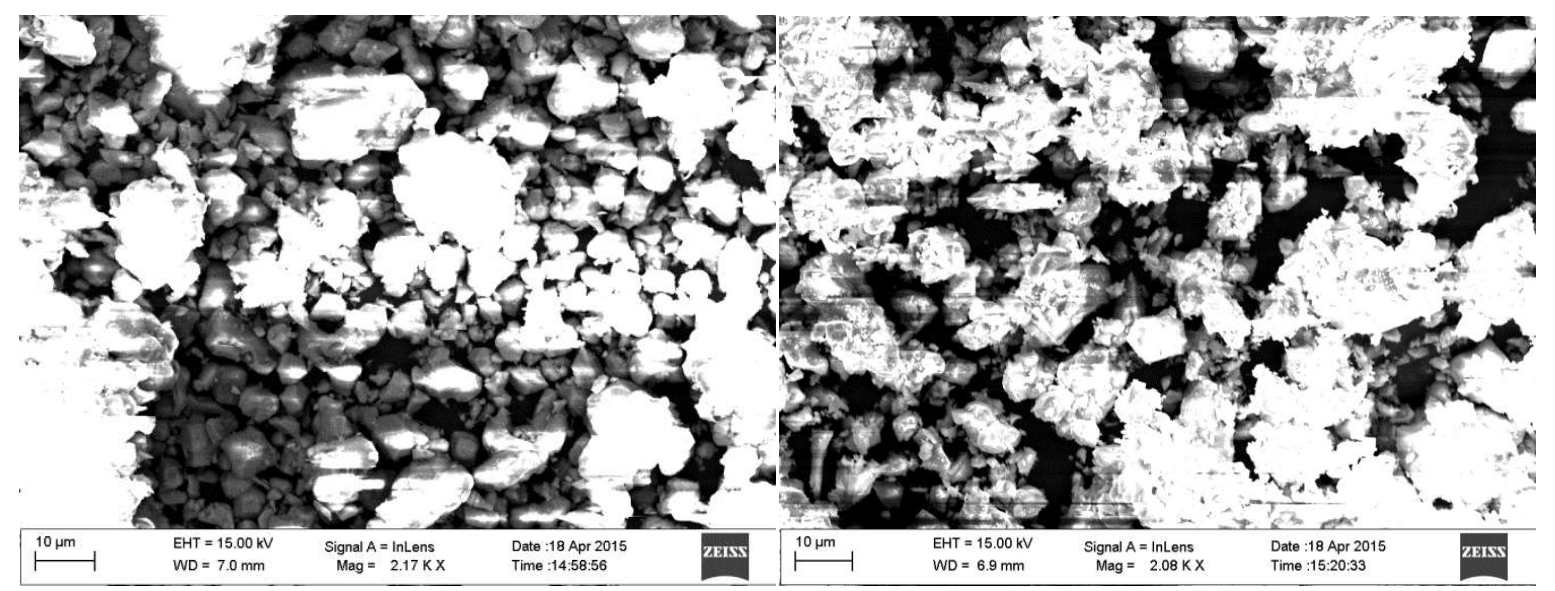

(c)

(d)

Fig. 2. SEM image of $\mathrm{LiNi}_{1-} \mathrm{Mg}_{\mathrm{x}} \mathrm{PO}_{4}$ ( $\mathrm{x}=0$, 0.05, 0.1 and 0.15); (a) $\mathrm{LiNiPO}_{4}$; (b) $\mathrm{LiNi}_{0.95} \mathrm{Mg}_{0.05} \mathrm{PO}_{4}$; (c) $\mathrm{LiNi}_{0.90} \mathrm{Mg}_{0.10} \mathrm{PO}_{4}$; (d) $\mathrm{LiNi}_{0.85} \mathrm{Mg}_{0.15} \mathrm{PO}_{4}$.

Table 2. Vibrational spectra data $\left(\mathrm{cm}^{-1}\right)$ and band assignments in $\mathrm{LiNi}_{1-\mathrm{x}} \mathrm{Mg}_{\mathrm{x}} \mathrm{PO}_{4}(x=0,0.05,0.1$ and 0.15$)$.

\begin{tabular}{|c|c|c|c|c|}
\hline \multicolumn{4}{|c|}{ Infrared wave number $\left[\mathrm{cm}^{-1}\right]$} & \multirow{2}{*}{ Assignmen } \\
\hline $\mathrm{x}=0$ & $=0.0$ & $x=0$. & $\mathrm{x}=0.15$ & \\
\hline 477 & 457 & 446 & 446 & $\mathrm{v}(\mathrm{Li}-\mathrm{O})$ \\
\hline 525 & 525 & 529 & 527 & $\mathrm{v}(\mathrm{Ni}-\mathrm{O})$ \\
\hline 547 & 548 & 548 & 548 & $\mathrm{v}_{2}\left(\mathrm{PO}_{4}\right)^{3-}$ \\
\hline 580 & 569 & 568 & 568 & $\mathrm{v}_{2}\left(\mathrm{PO}_{4}\right)^{3-}$ \\
\hline 653 & 649 & 649 & 649 & $\mathrm{v}_{4}\left(\mathrm{PO}_{4}\right)^{3-}$ \\
\hline 940 & 937 & 949 & 949 & $\mathrm{v}_{1}\left(\mathrm{PO}_{4}\right)^{3-}$ \\
\hline 1057 & 1060 & 1064 & 1035 & $\mathrm{v}_{3}\left(\mathrm{PO}_{4}\right)^{3-}$ \\
\hline 1100 & 1091 & 1090 & 1094 & $\mathrm{v}_{3}\left(\mathrm{PO}_{4}\right)^{3-}$ \\
\hline 1150 & 1139 & 1140 & 1134 & $\mathrm{v}_{3}\left(\mathrm{PO}_{4}\right)^{3-}$ \\
\hline
\end{tabular}




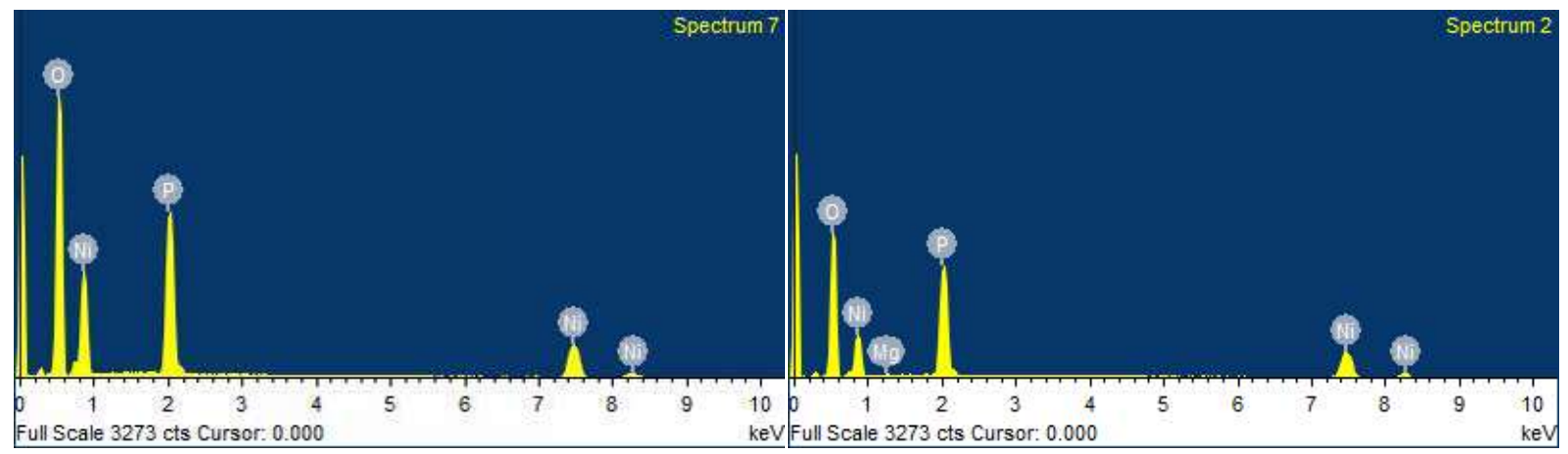

(a)

(b)

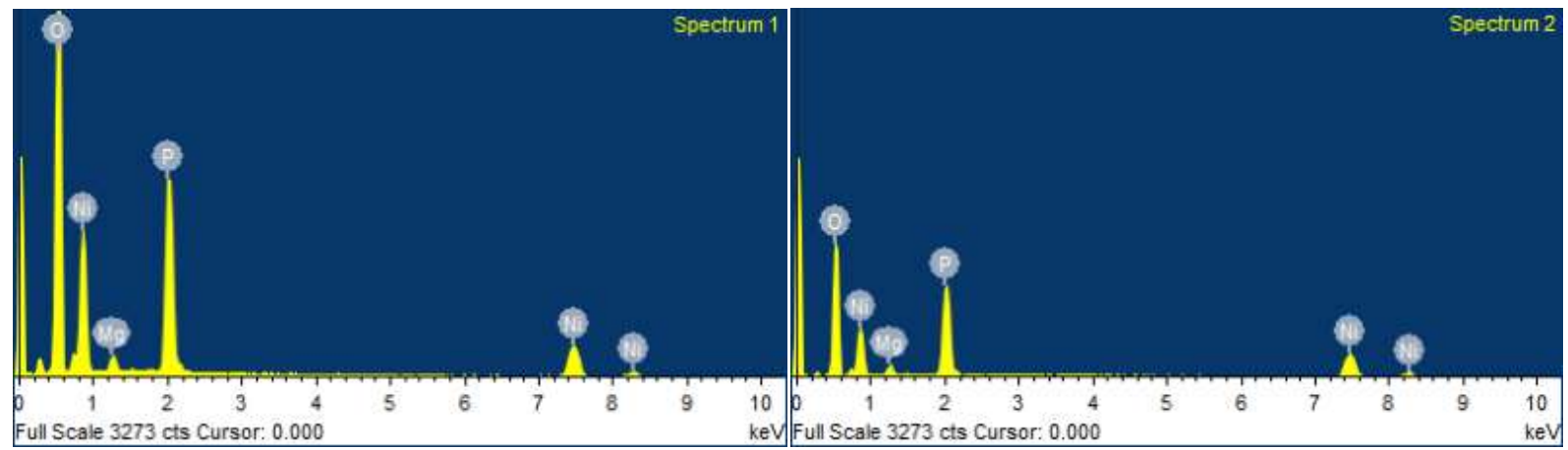

(c)

(d)

Fig. 3. EDS spectra for $\mathrm{LiNi}_{1-x} \mathrm{Mg}_{\mathrm{x}} \mathrm{PO}_{4}\left(\mathrm{x}=0,0.05\right.$, 0.1 and 0.15); (a) $\mathrm{LiNiPO}_{4}$; (b) $\mathrm{LiNi}_{0.95} \mathrm{Mg}_{0.05} \mathrm{PO}_{4}$; (c) $\mathrm{LiNi}_{0.90} \mathrm{Mg}_{0.10} \mathrm{PO}_{4} ;$ (d) $\mathrm{LiNi}_{0.85} \mathrm{Mg}_{0.15} \mathrm{PO}_{4}$.

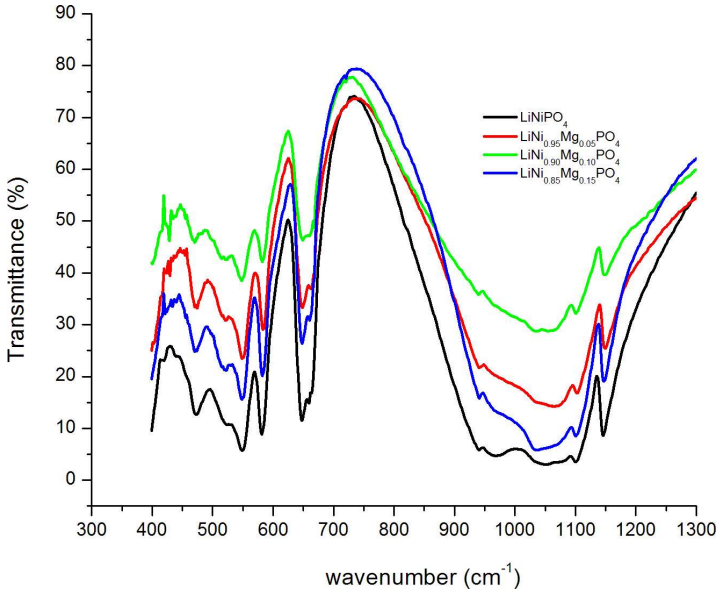

Fig. 4. FT-IR spectra for $\mathrm{LiNi}_{1-x} \mathrm{Mg}_{x} \mathrm{PO}_{4}(\mathrm{x}=0,0.05$, 0.1 and 0.15 ).

\subsection{Nyquist plots}

The cole-cole/Nyquist plots $\mathrm{LiNi}_{1-x} \mathrm{Mg}_{x} \mathrm{PO}_{4} \quad(\mathrm{x}=0,0.05,0.1$ and 0.15$)$ samples measured at various temperatures are shown in Fig. 5.

There are two semicircles in each impedance spectrum. The low frequency semicircle is due to the grain boundary and the high frequency semicircle depicts the bulk (grain) effect. The obtained curves for each sample appear in the form of single semicircles at various temperatures. No other curves are observed in the lower frequency region. Therefore, the semicircles of each sample are attributed to bulk conductivity, suggesting that the conductivity is of mixed electronic and ionic character. As shown in the figure, in the plots of $Z^{\prime}$ (the real part of the impedance) against $Z^{\prime \prime}$ (the imaginary part of the impedance), each arc begins from lower frequencies to the right direction of the $Z^{\prime}$ axis and ends to the left direction of $Z^{\prime}$-axis at higher frequencies. It is observed that resistivity of the samples dramatically decreases with the increase in temperature. As a result, the diameter of 


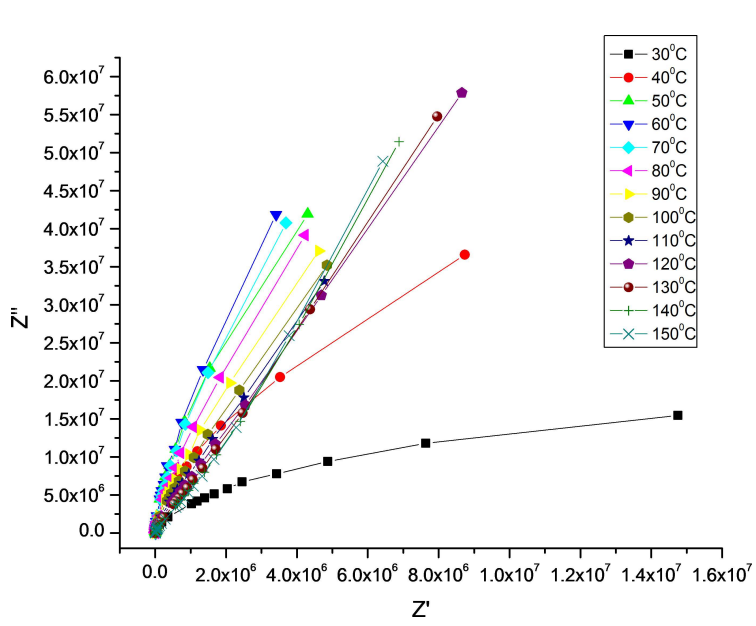

(a)

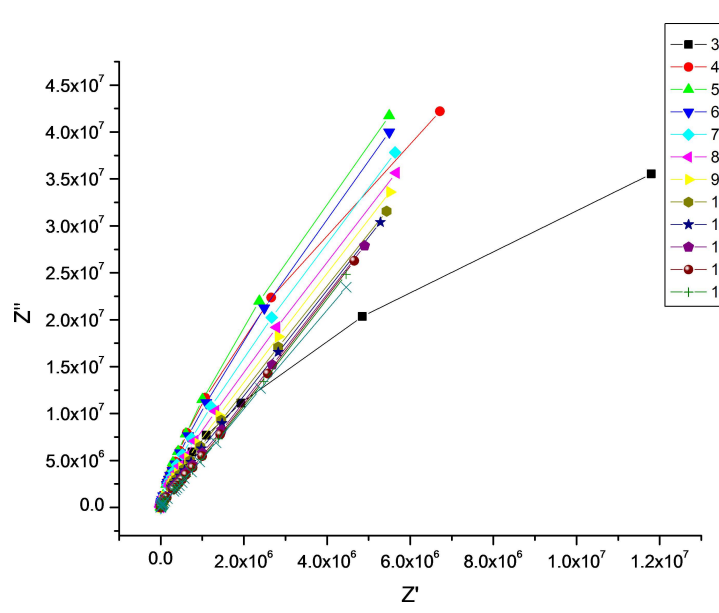

(c)

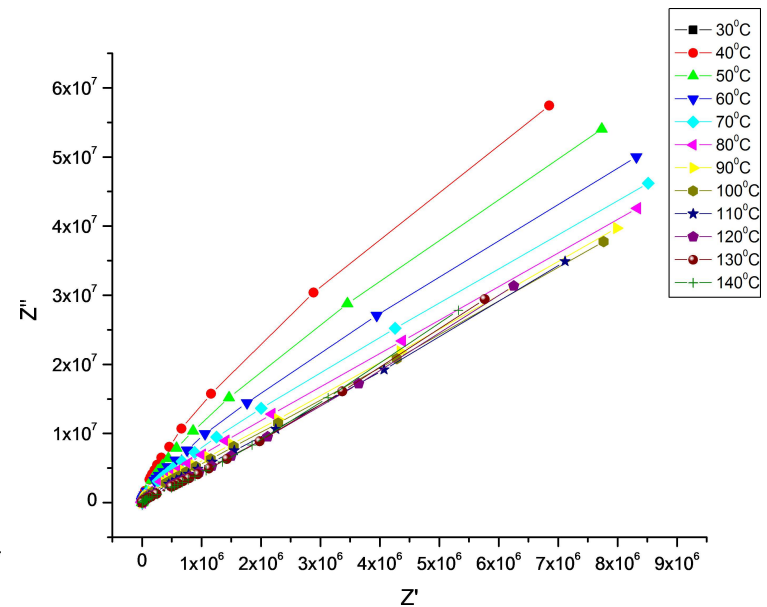

(b)

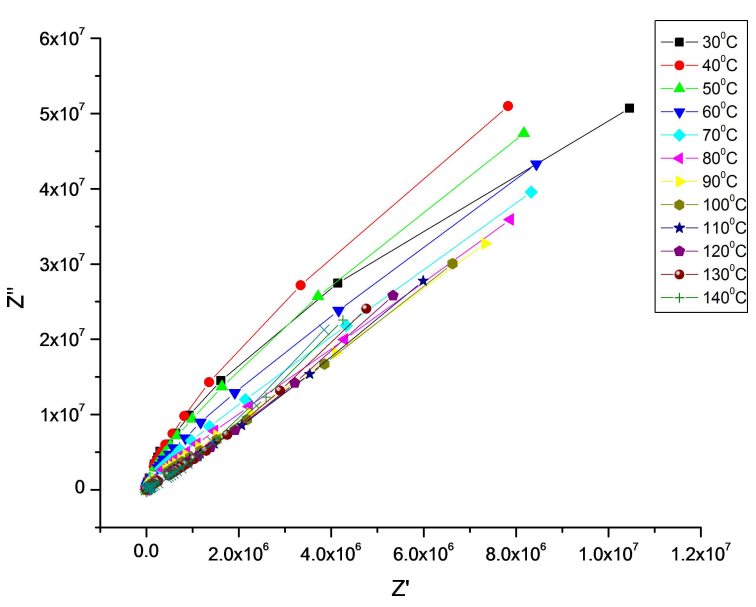

(d)

Fig. 5. Nyquist plots for the compounds $\mathrm{LiNi}_{1-\mathrm{x}} \mathrm{Mg}_{\mathrm{x}} \mathrm{PO}_{4}$ (a) $\mathrm{x}=0$, (b) $\mathrm{x}=0.05$, (c) $\mathrm{x}=0.1$, (d) $\mathrm{x}=0.15$.

the semicircle decreases with increasing temperature. On the other hand, it is observed that all arcs in the impedance plots are not perfect semicircles, which means that the highest frequency arcs do not intersect with the $Z^{\prime}$ axis [29-31].

The variations of real $\left(Z^{\prime}\right)$ and imaginary $\left(Z^{\prime \prime}\right)$ part of impedance with frequency at different temperatures of $\mathrm{LiNi}_{1-\mathrm{x}} \mathrm{Mg}_{\mathrm{x}} \mathrm{PO}_{4}(\mathrm{x}=0,0.05,0.1$ and 0.15) are shown in Fig. 6 and Fig. 7.

The value of $\mathrm{Z}^{\prime}$ decreases with an increase in frequency at low temperatures. The peak position shifts towards higher frequency side with a rise in temperature, as well as the width of the peak is also broadened with increasing temperature.
The asymmetric broadening of the peaks in $Z^{\prime}$ with frequency suggests that there is a spread of relaxation time. Also the shifting of relaxation peak indicates the existence of a temperature dependent electrical relaxation phenomenon in the material. The use of the imaginary part of the impedance $\left(Z^{\prime \prime}\right)$ is particularly appropriate for resistivity and/or conductivity analysis (when the long range conductivity is dominant) [32,33].

\subsection{Dielectric constant $\left(\epsilon^{\prime}\right)$}

The variation of the dielectric constant $\left(\varepsilon^{\prime}\right)$ as a function of frequency $(50 \mathrm{~Hz}$ to $5 \mathrm{MHz})$ at room temperature to $150{ }^{\circ} \mathrm{C}$ for $\mathrm{LiNi}_{1-\mathrm{x}} \mathrm{Mg}_{\mathrm{x}} \mathrm{PO}_{4}(\mathrm{x}=0$, $0.05,0.1$ and 0.15 ) samples is shown in Fig. 8. 


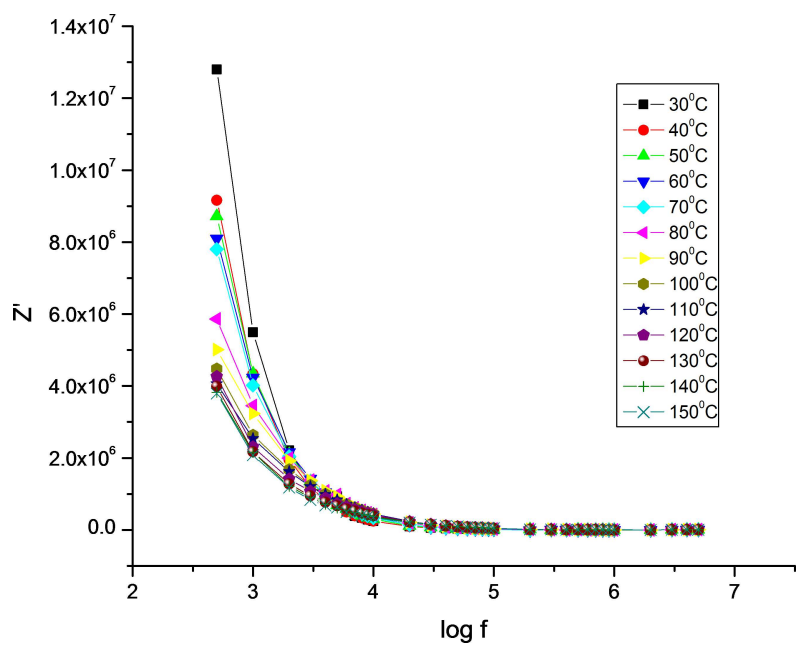

(a)

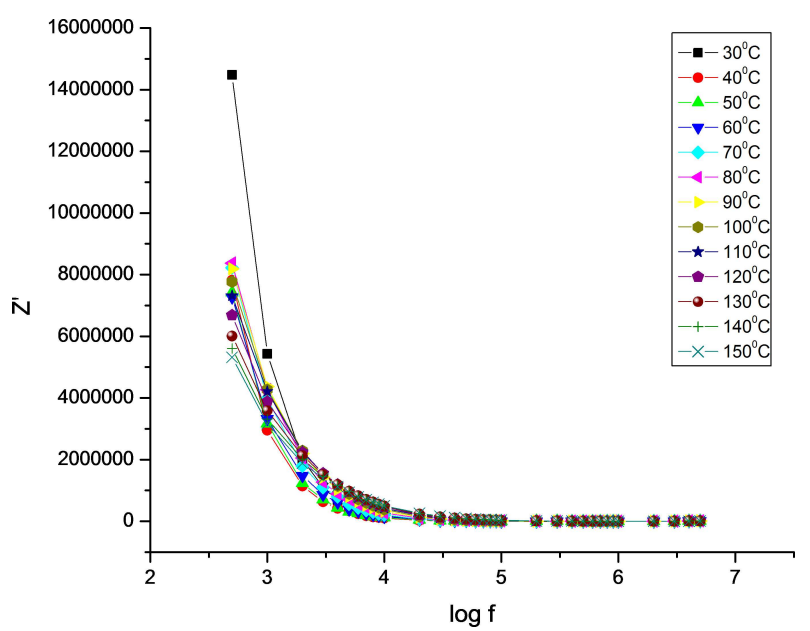

(c)

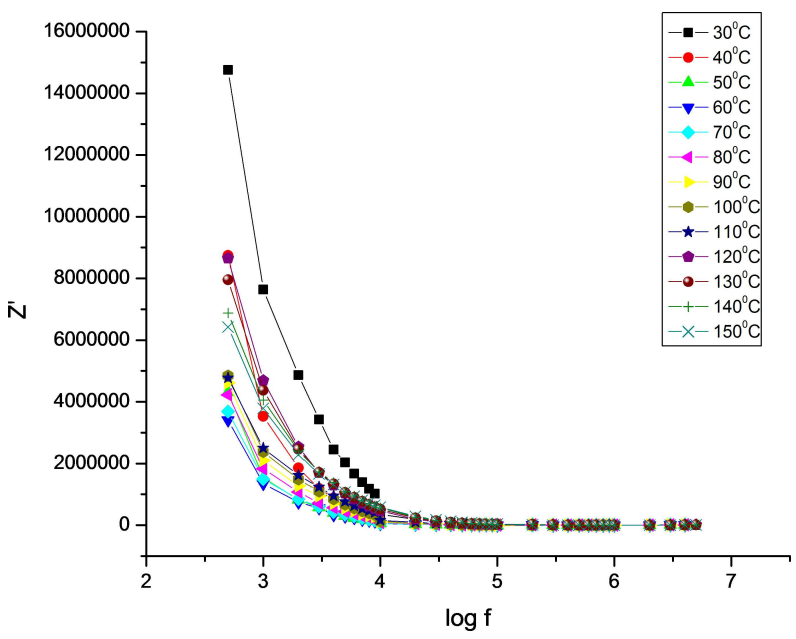

(b)

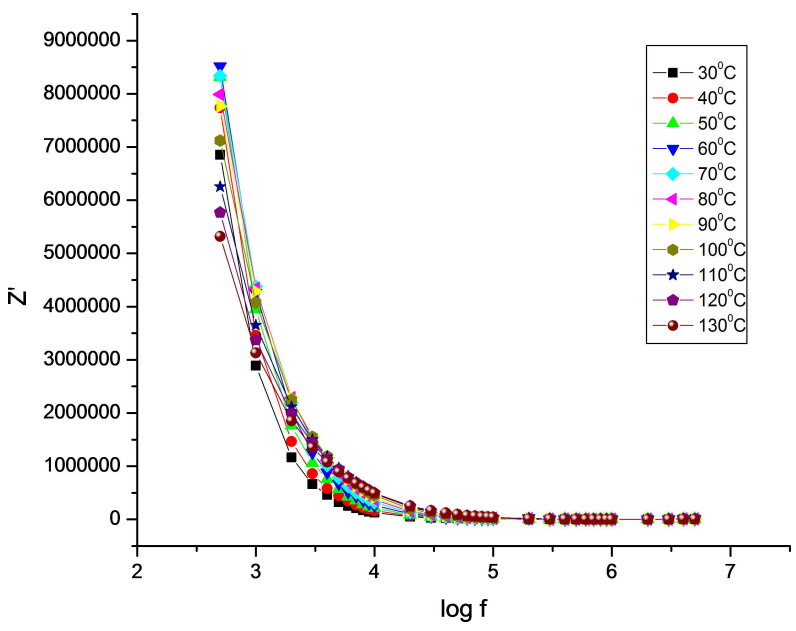

(d)

Fig. 6. Variation of $\mathrm{Z}^{\prime}$ with frequency for the compounds $\mathrm{LiNi}_{1-\mathrm{x}} \mathrm{Mg}_{\mathrm{x}} \mathrm{PO}_{4}$ (a) $\mathrm{x}=0$, (b) $\mathrm{x}=0.05$, (c) $\mathrm{x}=0.1$, (d) $\mathrm{x}=0.15$.

From the frequency dependent plot of $\varepsilon^{\prime}$, it is observed that the value of $\varepsilon^{\prime}$ decreases sharply as the frequency increases and attains a constant limiting value, at which $\varepsilon^{\prime}$ becomes almost frequency independent. The higher values of dielectric constant at low frequencies can be due to pileup of charges at the interfaces between the sample and the electrode. This can be explained based on the behavior of dipole movement as follows. Dielectric behavior of samples with frequency is related to the applied electric field. An alternating electric field changes its direction with time. With each direction reversal, the polarization components are required to follow the field reversal. So, the polarization depends on the ability of dipoles to orient themselves in the direction of the field during each alternative change of the field. At low frequency regions the dipoles will get sufficient time to orient themselves completely along the direction of the field, resulting in larger values of $\varepsilon^{\prime}$ of the samples. As the frequency increases further, the dipoles in the sample cannot reorient themselves 


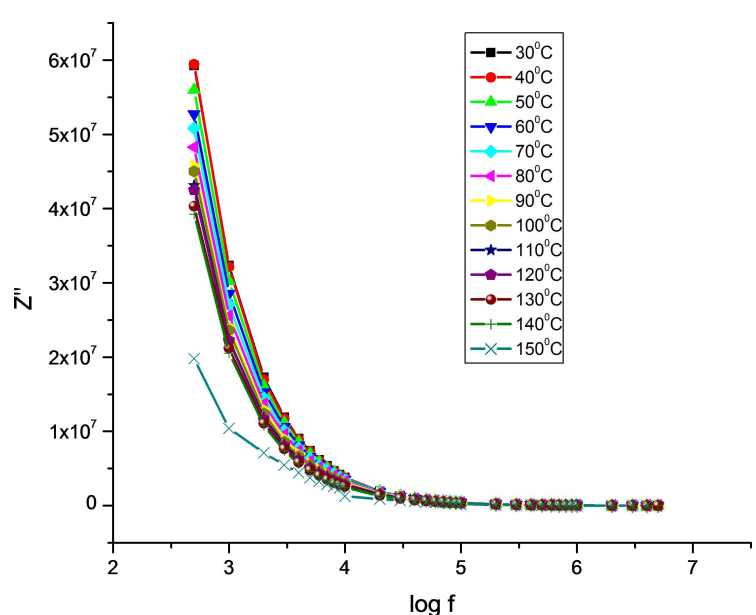

(a)

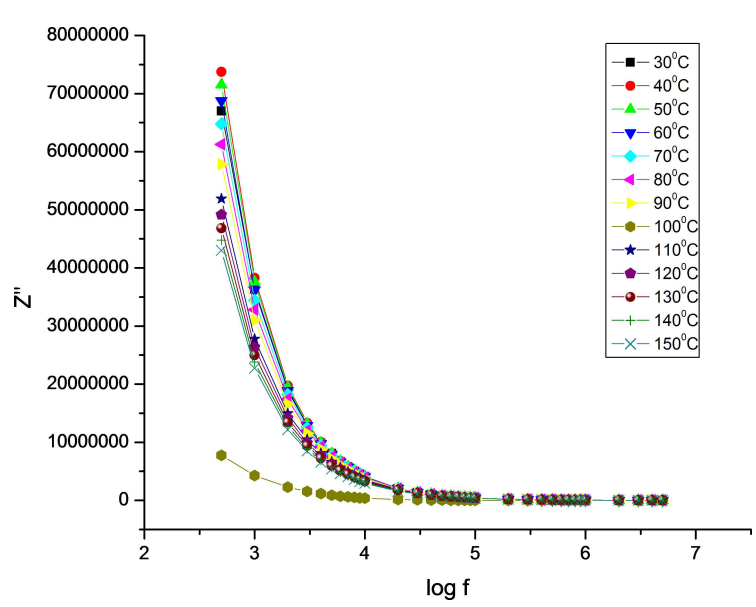

(c)

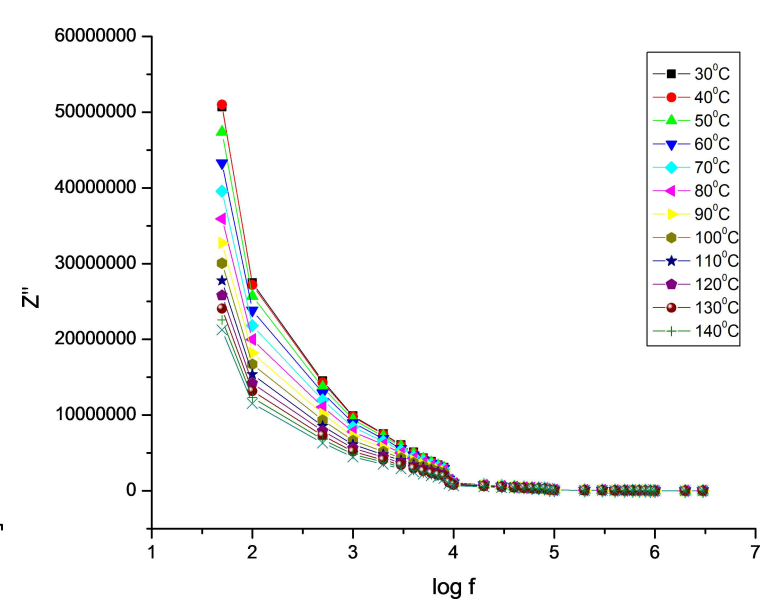

(b)

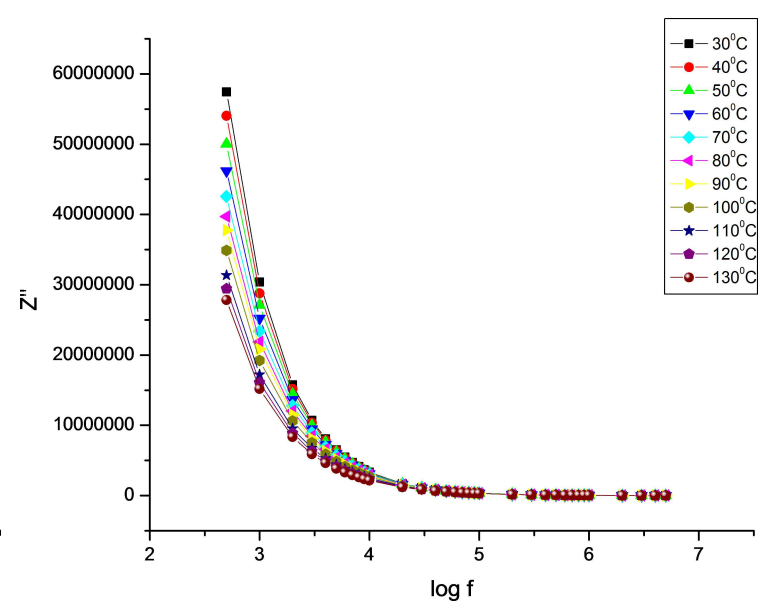

(d)

Fig. 7. Variation of $Z^{\prime \prime}$ with frequency for the compounds $\mathrm{LiNi}_{1-\mathrm{x}} \mathrm{Mg}_{\mathrm{x}} \mathrm{PO}_{4}$ (a) $\mathrm{x}=0$, (b) $\mathrm{x}=0.05$, (c) $\mathrm{x}=0.1$, (d) $\mathrm{x}=0.15$.

fast enough to respond to the applied electric field, resulting in the decrease in $\varepsilon^{\prime}$ of the samples and becoming almost constant $[34,35]$.

\subsection{Dielectric permittivity $\left(\varepsilon^{\prime \prime}\right)$ and dielec- tric loss $(\tan \delta)$}

The dielectric loss can be divided into three parts: conduction losses, dipole losses and vibrational losses. The loss that is attributed to conduction presumably involves the migration of ions over large distances. This motion is the same as that occurring under direct current conduction. The variation of dielectric permittivity $\left(\varepsilon^{\prime \prime}\right)$ with frequency is shown in Fig. 9. The variation of the dielectric loss $\tan \delta$ with the frequency at different temperatures is shown in Fig. 10 for the compound $\mathrm{LiNi}_{1-\mathrm{x}} \mathrm{Mg}_{\mathrm{x}} \mathrm{PO}_{4}(\mathrm{x}=0,0.05,0.1$ and 0.15$)$. The magnitude of the dielectric loss increases with an increase in temperature. At low temperature, conduction losses have minimum value. As the temperature increases AC conductivity also increases, so the conduction losses increase. This leads to an increase of the value of $\tan \delta$ with temperature. The increase of the dielectric loss at low frequency is due to dipole polarization [36-38].

\subsection{AC conductivity $\left(\sigma_{\mathrm{ac}}\right)$}

The electrical conductivity studies of the synthesized compounds have been carried out over a frequency range of $50 \mathrm{~Hz}$ to $5 \mathrm{MHz}$ in 


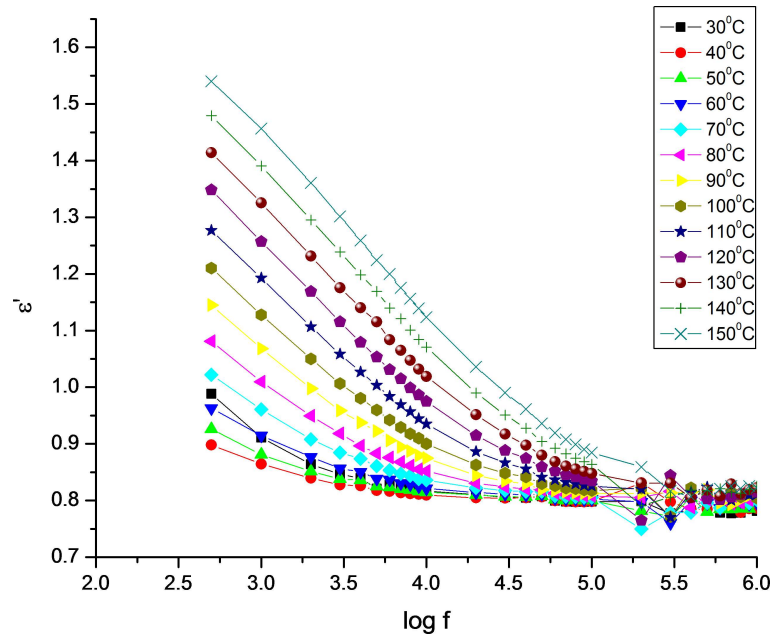

(a)

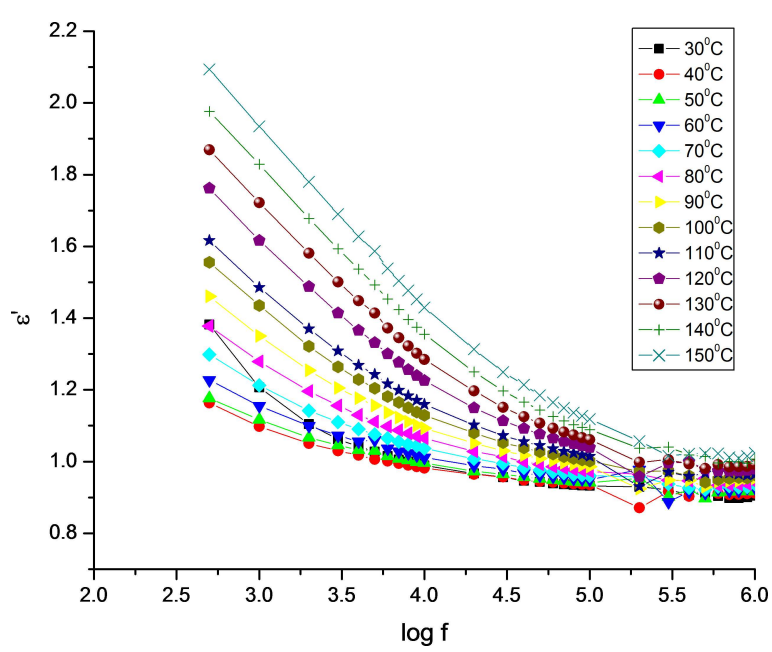

(c)

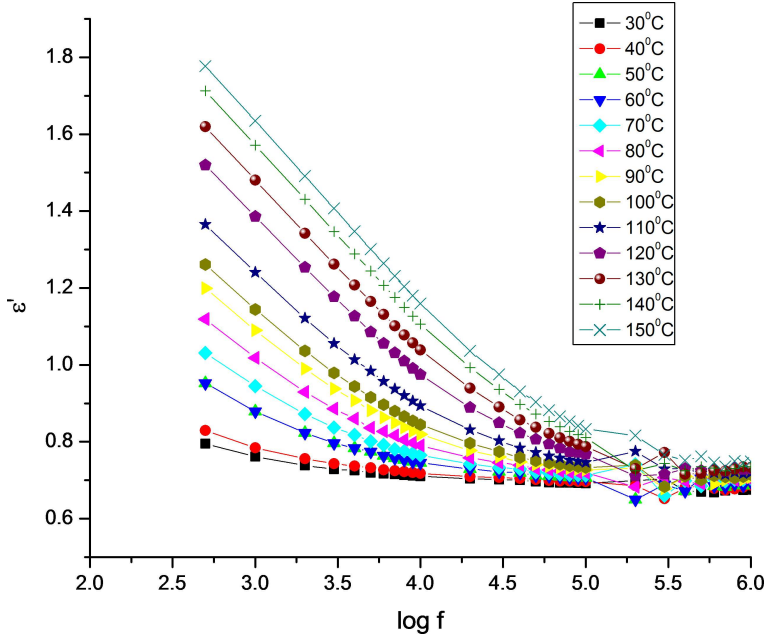

(b)

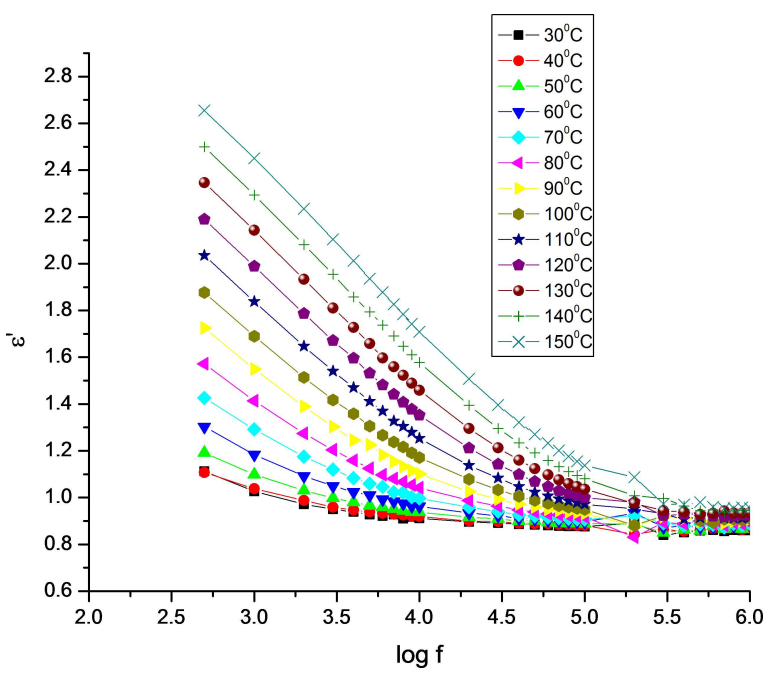

(d)

Fig. 8. Variation of real part of dielectric permittivity $\left(\varepsilon^{\prime}\right)$ with frequency for the compounds $\mathrm{LiNi}_{1-\mathrm{x}} \mathrm{Mg}_{\mathrm{x}} \mathrm{PO}_{4}$ (a) $\mathrm{x}=0$, (b) $\mathrm{x}=0.05$, (c) $\mathrm{x}=0.1$, (d) $\mathrm{x}=0.15$.

the temperature range of $30{ }^{\circ} \mathrm{C}$ to $150{ }^{\circ} \mathrm{C}$. The conductivities are found to be $\sim 10^{-6} \mathrm{~S} / \mathrm{cm}$ at room temperature and higher temperature respectively for all the doped samples. The AC conductivity is calculated from dielectric data using the relation:

$$
\sigma_{a c}=\omega \varepsilon_{r} \varepsilon_{0} \tan \delta
$$

where $\omega=2 \pi f$.

The calculated conductivity results for all samples at different temperature ranges are compared in Table 3. The obtained results are found to be dependent on temperature as well as concentration of substituted Mg ions. It is observed that the conductivity of each sample increases with an increase in temperature, indicating that the electrical conduction in the samples is a thermally activated process. Thus, the observed electrical conductivity is found to occur due to the hopping of small polarons associated with the behavior of changeable oxidation state of the transition metal ions. As the temperature increases, the polarons have sufficient thermal energy to get activated and jump over the barrier 


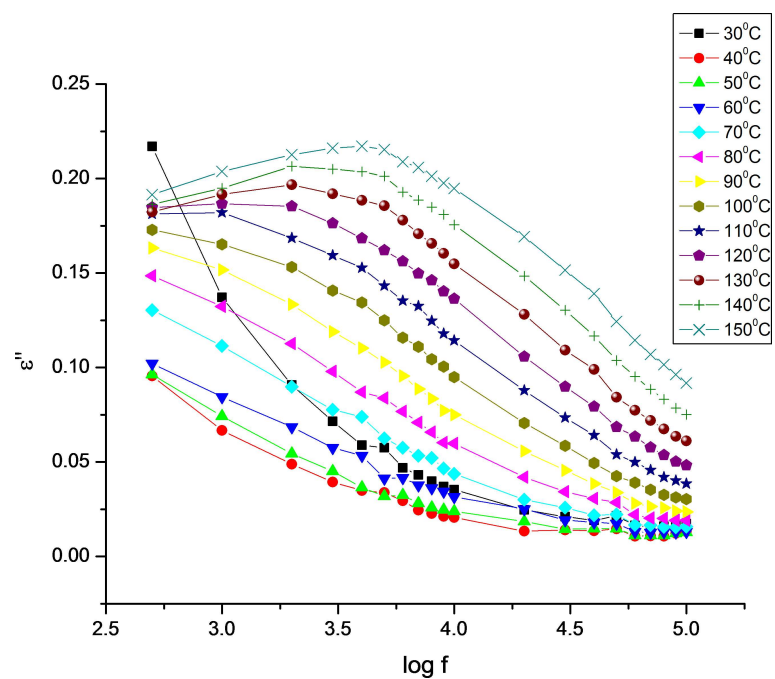

(a)

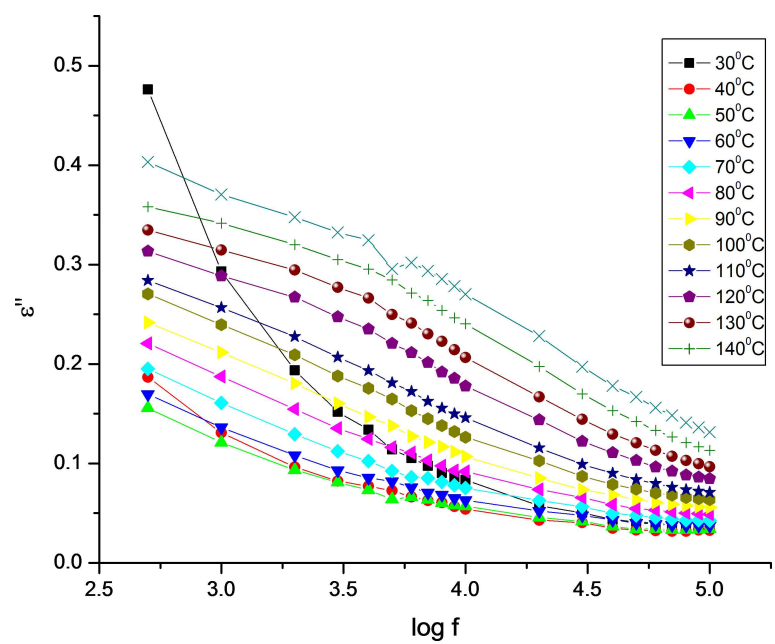

(c)

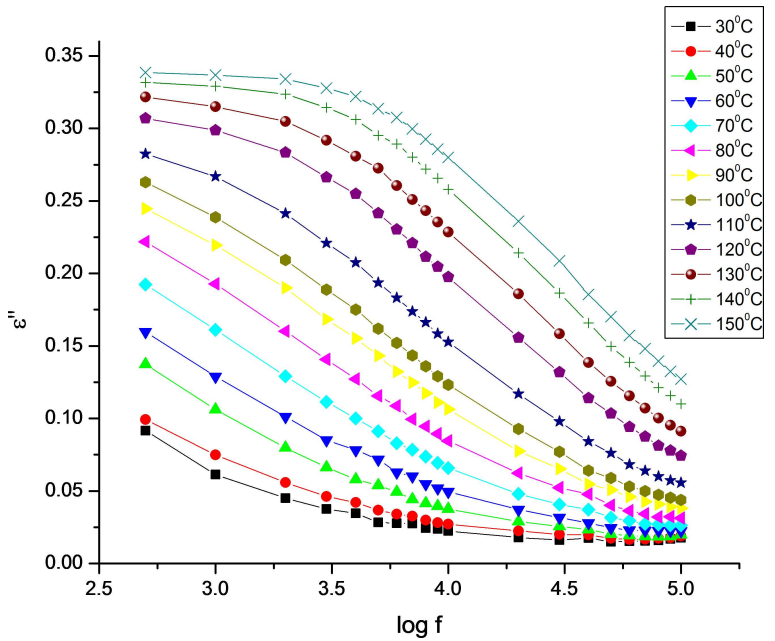

(b)

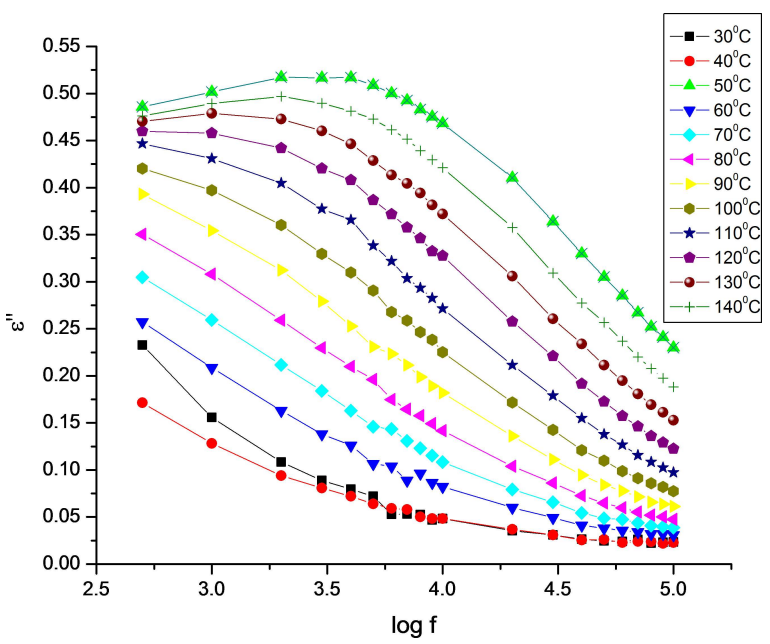

(d)

Fig. 9. Variation of imaginary part of dielectric permittivity $\left(\varepsilon^{\prime \prime}\right)$ with frequency for the compounds $\mathrm{LiNi}_{1-\mathrm{x}} \mathrm{Mg}_{\mathrm{x}} \mathrm{PO}_{4}$ (a) $\mathrm{x}=0$, (b) $\mathrm{x}=0.05$, (c) $\mathrm{x}=0.1$, (d) $\mathrm{x}=0.15$.

and that is why larger values of conductivity of the samples are observed at higher temperatures. Also, the room temperature conductivity is found to be $9.47 \times 10^{-10}, 2.95 \times 10^{-9}, 9.62 \times 10^{-10}$, $9.80 \times 10^{-10} \mathrm{~S} / \mathrm{cm}$ for $\mathrm{LiNi}_{1-x} \mathrm{Mg}_{\mathrm{x}} \mathrm{PO}_{4}(\mathrm{x}=$ $0,0.05,0.1$ and 0.15 ), respectively. These results are in the range of the electrical conductivity of semiconductors $\left(10^{-10} \mathrm{~S} / \mathrm{cm}\right.$ to $\left.10^{-9} \mathrm{~S} / \mathrm{cm}\right)$, indicating the semiconductor behavior of the samples [39, 40].

The variation of the AC conductivity as a function of frequency (from $50 \mathrm{~Hz}$ to $5 \mathrm{MHz}$ ) at room
Table 3. Activation energies for different compounds at $100 \mathrm{kHz}$.

\begin{tabular}{lcc}
\hline \multicolumn{1}{c}{ Compound } & $\begin{array}{c}\text { AC conductivity } \\
{[\mathrm{S} / \mathrm{cm}]}\end{array}$ & $\begin{array}{c}\text { Activation } \\
\text { energy [eV] }\end{array}$ \\
\hline \hline $\mathrm{LiNiPO}_{4}$ & $9.47 \times 10^{-10}$ & 0.47 \\
$\mathrm{LiNi}_{0.95} \mathrm{Mg}_{0.05} \mathrm{PO}_{4}$ & $2.95 \times 10^{-9}$ & 0.56 \\
$\mathrm{LiNi}_{0.90} \mathrm{Mg}_{0.10} \mathrm{PO}_{4}$ & $9.62 \times 10^{-10}$ & 0.52 \\
$\mathrm{LiNi}_{0.85} \mathrm{Mg}_{0.15} \mathrm{PO}_{4}$ & $9.80 \times 10^{-10}$ & 0.66 \\
\hline
\end{tabular}

temperature to $150{ }^{\circ} \mathrm{C}$ for $\mathrm{LiNi}_{1-\mathrm{x}} \mathrm{Mg}_{\mathrm{x}} \mathrm{PO}_{4}(\mathrm{x}=0$, $0.05,0.1$ and 0.15$)$ samples is shown in Fig. 11. It 


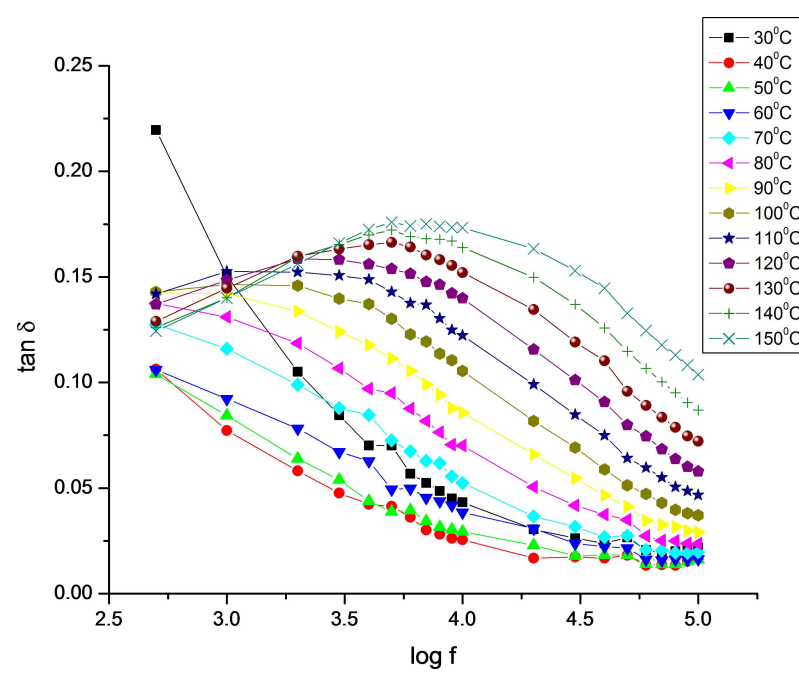

(a)

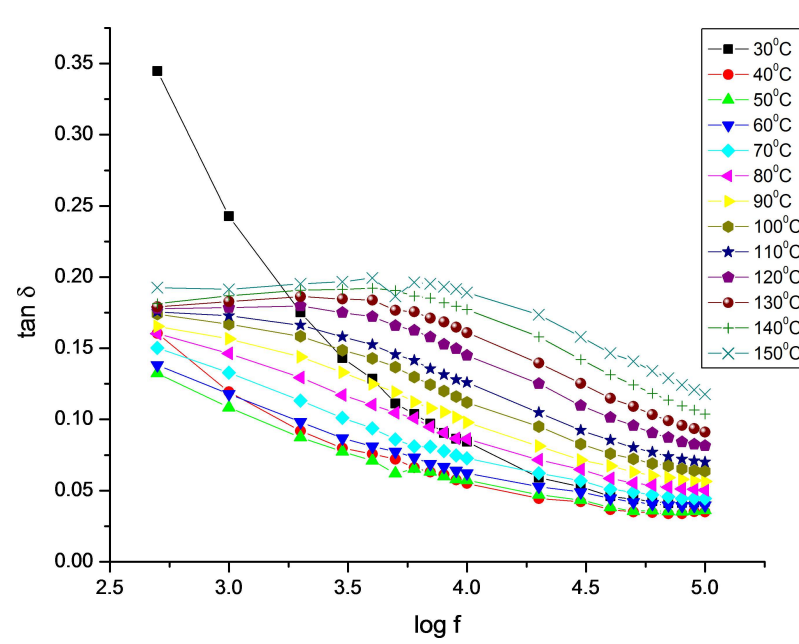

(c)

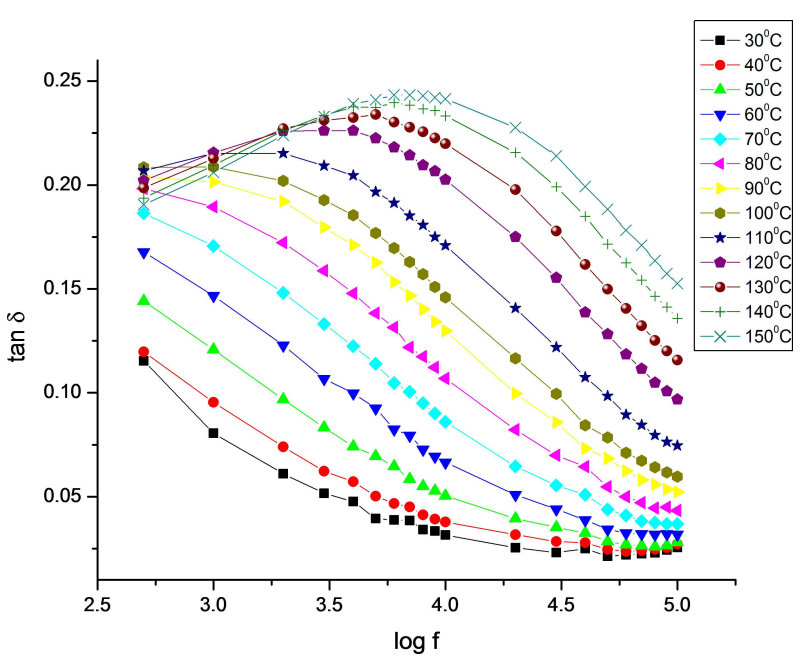

(b)

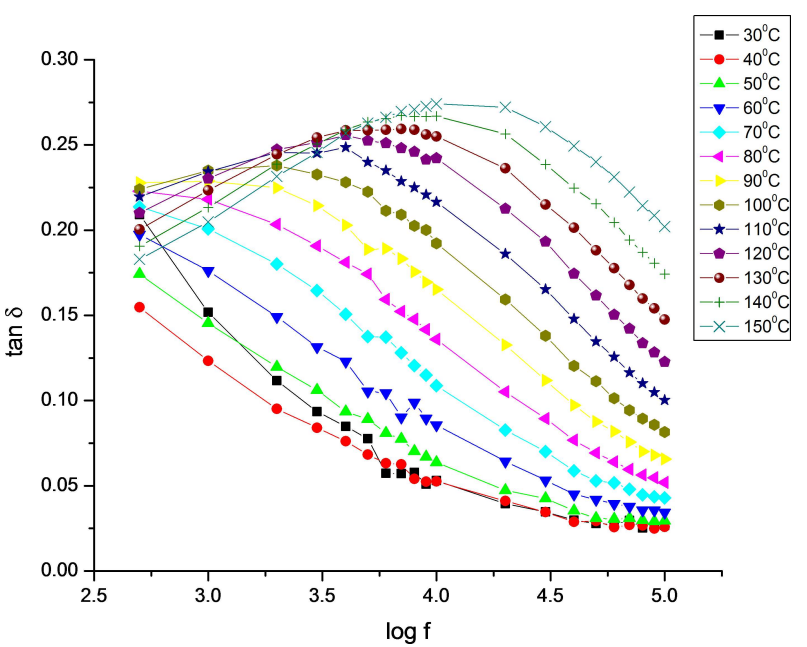

(d)

Fig. 10. Variation of $\tan \delta$ with frequency for the compounds $\mathrm{LiNi}_{1-x} \mathrm{Mg}_{x} \mathrm{PO}_{4}$ (a) $\mathrm{x}=0$, (b) $\mathrm{x}=0.05$, (c) $\mathrm{x}=0.1$, (d) $\mathrm{x}=0.15$.

is clearly observed that the AC conductivity curves show two distinct regions. The first one is the low frequency region in which the conductivity is almost frequency independent, which corresponds to the random hopping of charges. The second one is the high frequency region in which the conductivity increases rapidly and reaches the highest value at $5 \mathrm{MHz}$, corresponding to frequency dependent conductivity. This behavior is characteristic of hopping of charges between the trap levels situated in the band gap. These two types of conductivities are observed in all samples.

\subsection{Electric modulus}

The electric modulus data were calculated using the real and imaginary parts of the measured impedance data and the pellet dimensions. The relaxation behavior was analyzed using the complex electric modulus $\left(\mathrm{M}^{*}=\mathrm{M}^{\prime}+\mathrm{j} \mathbf{M}^{\prime \prime}\right)$ formalism. The calculated $\mathrm{M}$ as a function of frequency for $\mathrm{LiNi}_{1-\mathrm{x}} \mathrm{Mg}_{\mathrm{x}} \mathrm{PO}_{4}(\mathrm{x}=0,0.05,0.1$, and 0.15) samples were fitted to the KohlrauschWilliam-Watts (KWW) expression. Fig. 12 shows the imaginary part of electric modulus $\mathrm{M}^{\prime}$ vs. $\log f$ 


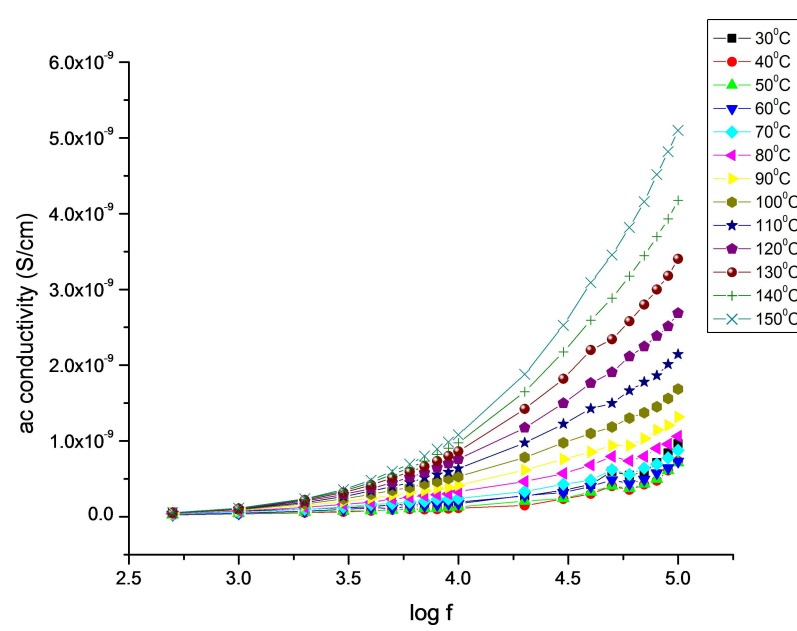

(a)

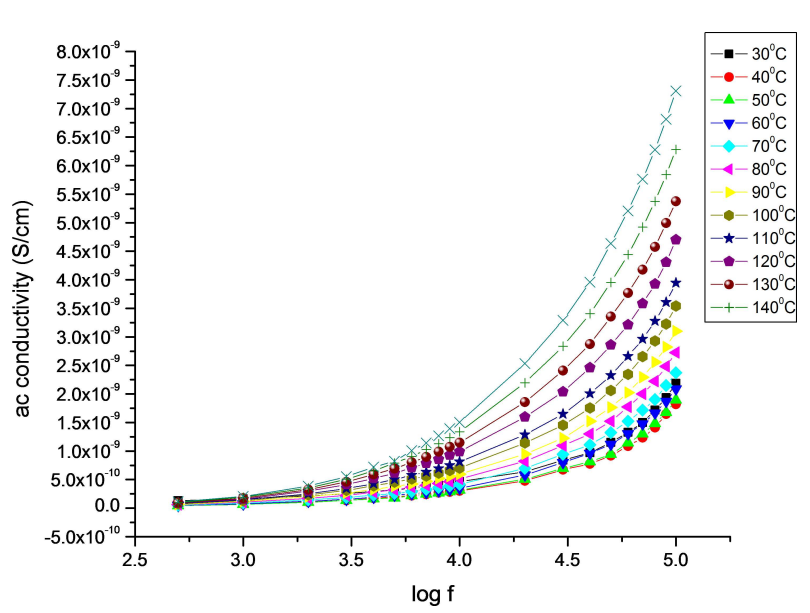

(c)

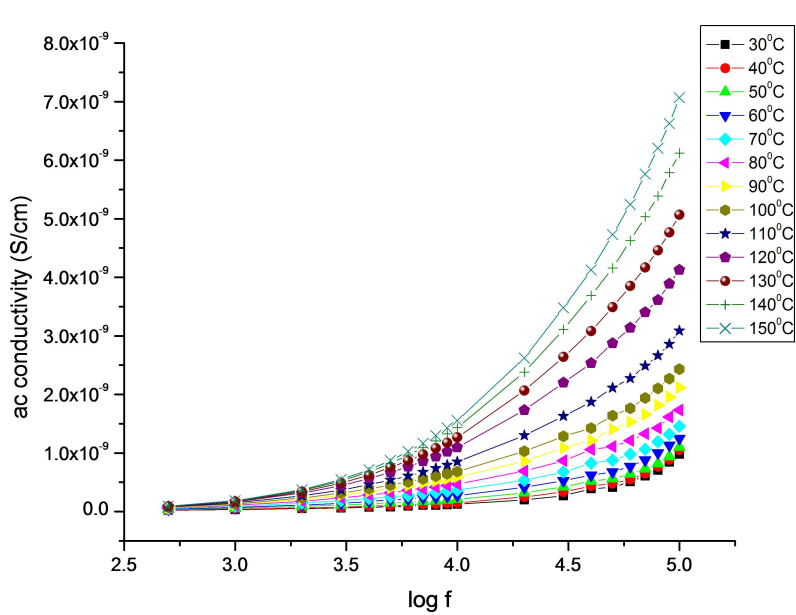

(b)

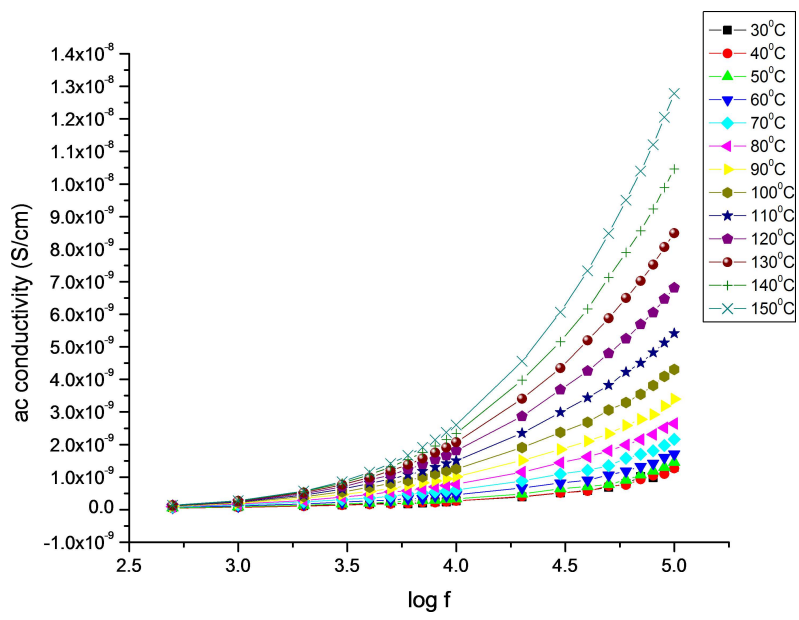

(d)

Fig. 11. Variation of $\mathrm{AC}$ conductivity with frequency for the compounds $\mathrm{LiNi}_{1-\mathrm{x}} \mathrm{Mg}_{\mathrm{x}} \mathrm{PO}_{4}$ (a) $\mathrm{x}=0$, (b) $\mathrm{x}=0.05$, (c) $\mathrm{x}=0.1,(\mathrm{~d}) \mathrm{x}=0.15$.

spectra obtained from RT to $150{ }^{\circ} \mathrm{C}$ for the synthesized compounds. From the figure, it is observed that the shape of each curve is of asymmetric nonLorentzian type, exhibiting a peak at the relaxation frequency with a long tail extending in the region of shorter relaxation time and a shift in peak height and frequency.

A comparison of the experimental data in the $\mathrm{M}^{*}$ and $\varepsilon^{*}$ formalism is useful to distinguish the long-range conduction process from the localized dielectric relaxation. To visualize this, we have plotted the imaginary part of complex dielectric permittivity $\left(\varepsilon^{\prime \prime}\right)$ and modulus $\left(\mathrm{M}^{\prime}\right)$ as a function of frequency for olivine $\mathrm{LiNi}_{1-\mathrm{x}} \mathrm{Mg}_{\mathrm{x}} \mathrm{PO}_{4}(\mathrm{x}=0$,
$0.05,0.1$ and 0.15$)$ cathode materials. Dielectric relaxation is a result of the reorientation process of dipoles in the metal-ion chains, which shows a peak in $\varepsilon^{\prime \prime}$ spectra. For cathode materials (with higher ionic concentration), the movement of ions from one site to another will perturb the electric potential of the surroundings. Motion of the other ions in this region will be affected by the perturbed potential. Such a cooperative motion of ions will lead to non-exponential decay, or a conduction processes with distribution of relaxation time. It has been observed that in the real part of modulus spectra, a relaxation peak occurs for the conductivity processes, whereas no peak is observed in 


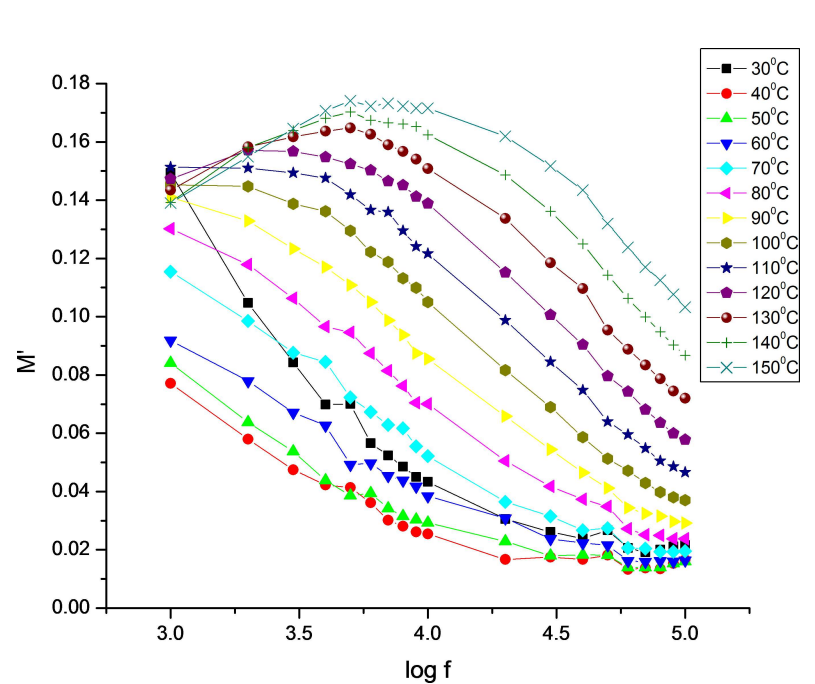

(a)

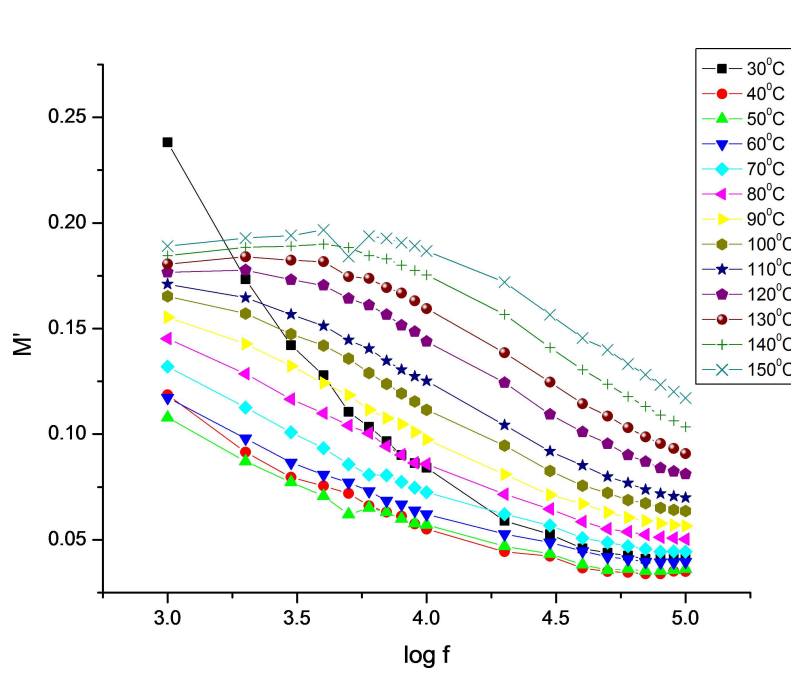

(c)

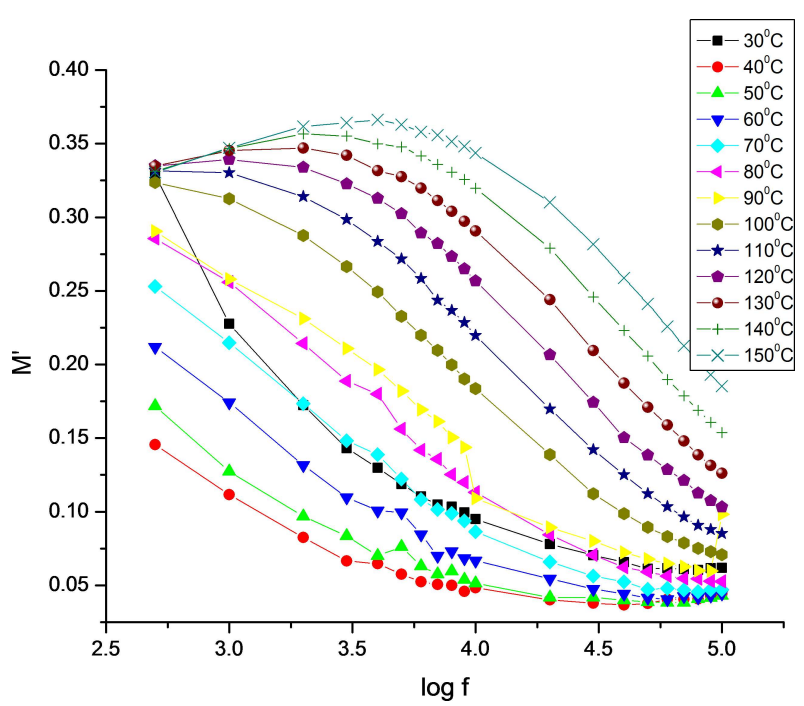

(b)

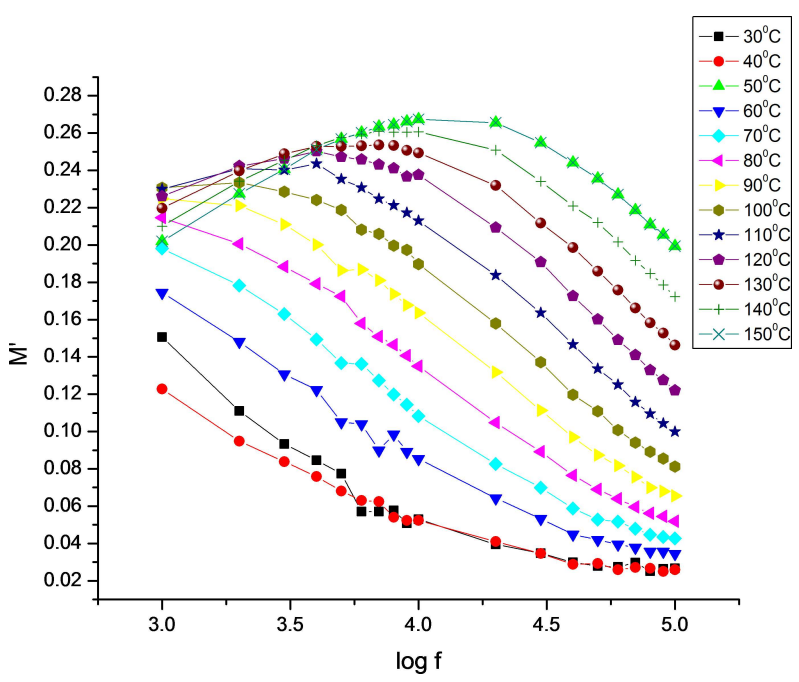

(d)

Fig. 12. Variation of $\mathrm{M}^{\prime}$ with frequency for the compounds $\mathrm{LiNi}_{1-} \mathrm{Mg}_{\mathrm{x}} \mathrm{PO}_{4}$ (a) $\mathrm{x}=0$, (b) $\mathrm{x}=0.05$, (c) $\mathrm{x}=0.1$, (d) $\mathrm{x}=0.15$.

the dielectric spectra. This suggests that the ionic motion and electronic segmental motion are strongly coupled, manifesting as a single peak in the M' spectra with no corresponding feature in dielectric spectra. So, the conduction in cathode materials takes place through charge migration of ions between coordinated sites of the polymer along with the segmental relaxation of polymer. An enhanced ionic conduction is a natural consequence of a type of cathode material [41,42].

\subsection{Activation energy $\left(\mathbf{E}_{\mathrm{a}}\right)$}

The increase in conductivity with increasing temperature indicates a characteristic activated behavior in the studied temperature range. Analysis of the frequency-dependent conductivity suggests that the electrical conduction in lithium orthophosphates is presumably caused by the hopping of lithium ions between octahedral sites of the olivine framework. At room temperature, 


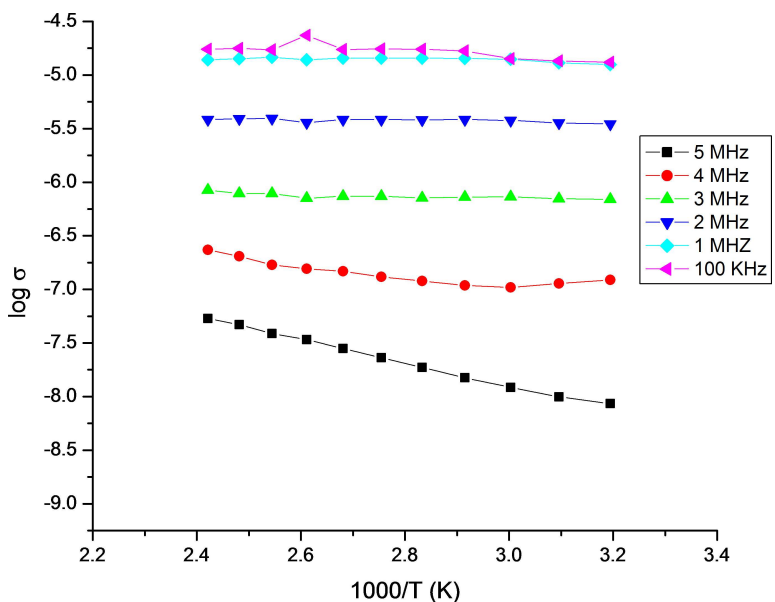

(a)

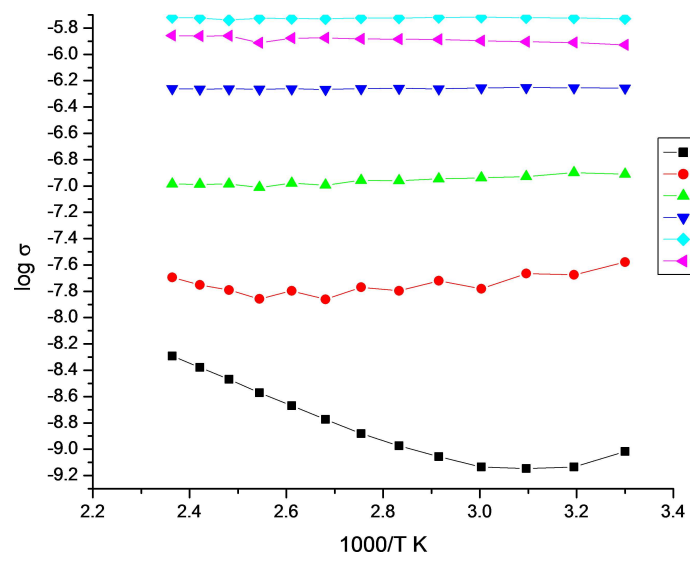

(c)

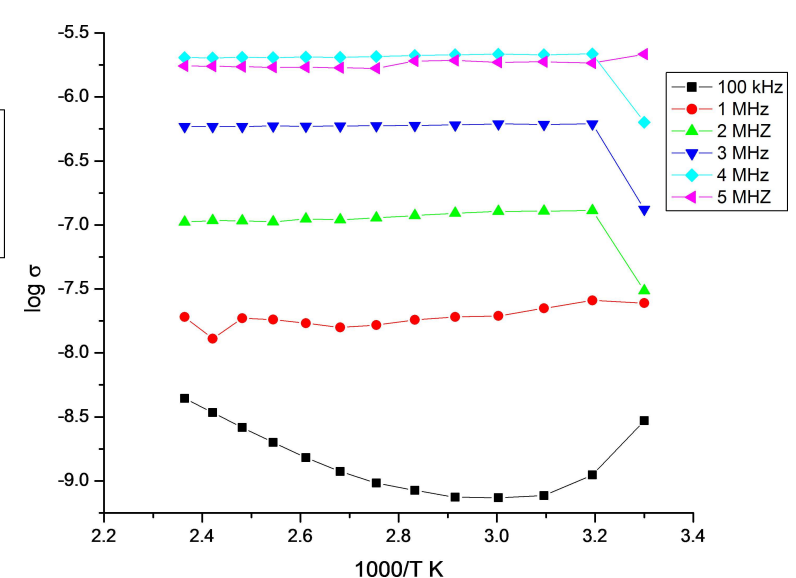

(b)

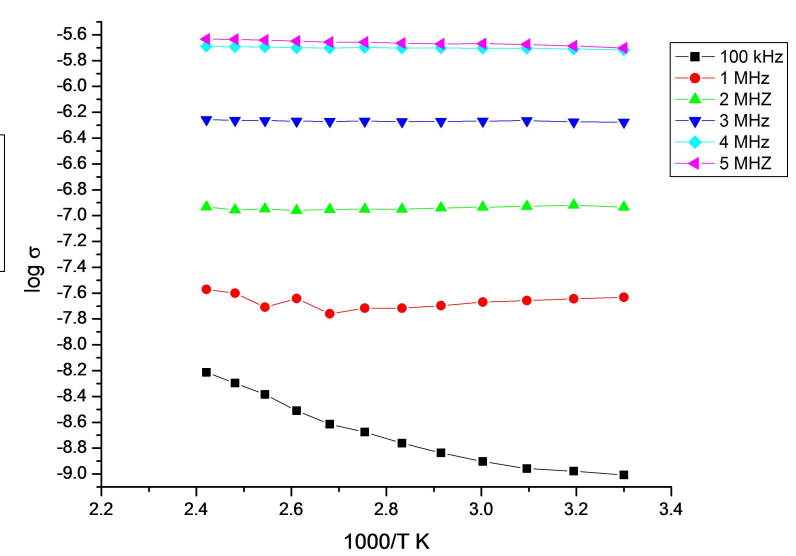

(d)

Fig. 13. Arrhenius plots for $\mathrm{LiNi}_{1-} \mathrm{Mg}_{\mathrm{x}} \mathrm{PO}_{4}$ (a) $\mathrm{x}=0$, (b) $\mathrm{x}=0.05$, (c) $\mathrm{x}=0.1$, (d) $\mathrm{x}=0.15$.

conductivity is found to be $10^{-8} \mathrm{~S} / \mathrm{cm}$, since the increased repulsion between $\mathrm{Li}^{+}$and $\mathrm{M}^{2+}$ cations reduces the strength of the $\mathrm{Li}-\mathrm{O}$ bonds resulting in higher conductivity. From impedance measurements, the activation energies $\mathrm{E}_{\mathrm{a}}$ was derived from Arrhenius equation, yielding activation energy in the range of $4 \mathrm{eV}$ for $\mathrm{LiNi}_{1-\mathrm{x}} \mathrm{Mg}_{\mathrm{x}} \mathrm{PO}_{4}(\mathrm{x}=0,0.05$, 0.1 and 0.15$)$. Fig. 13 shows that the activation energy decreases with the increasing magnesium concentration. The change in the activation energy is due to the lattice shrinkage [43].

\section{Conclusions}

The magnesium substituted olivine $\mathrm{LiNi}_{1-\mathrm{x}} \mathrm{Mg}_{\mathrm{x}} \mathrm{PO}_{4}(\mathrm{x}=0,0.05,0.1$ and, 0.15) cathode materials have been successfully synthesized by solid-state reaction method at low temperature. Different properties of the materials were studied using different techniques. The XRD studies confirmed that all the synthesized samples belong to the Pnma space group. It was also observed that an increase of the $\mathrm{Mg}$ content $\mathrm{x}=0,0.05,0.1$ and 0.15 caused the decrease in lattice parameter, unit cell volume and crystallite size. The porosity nature of the samples was also observed in SEM studies. An increase in wave number for most of the bands indicated that both the $\mathrm{P}-\mathrm{O}$ and $\mathrm{M}-\mathrm{O}(\mathrm{Ni}$ or $\mathrm{Mg}$ ) bonds strengthened as a result of substitution of $\mathrm{Mg}$ in $\mathrm{LiNi}_{1-\mathrm{x}} \mathrm{Mg}_{\mathrm{x}} \mathrm{PO}_{4}$ due to the transverse asymmetric mode of vibration. Both the dielectric constant $\left(\varepsilon^{\prime}\right)$ and dielectric loss $\left(\varepsilon^{\prime \prime}\right)$ increased with temperature and decreased with frequency through the studied 
ranges. The dielectric constant may be attributed to orientation and space charge polarization respectively, as the temperature dependence of the dielectric loss is associated with the conduction loss.

\section{References}

[1] TArascon J.M., ARmand M., Nature, 414 (2001), 359.

[2] Morgan D., van der Ven A., Ceder G., Electrochem. Solid St., 7 (2004), A30.

[3] OKada S., SaWA S., Egashira M., Yamaki J., Tabuchi M., Kageyama H., Konishi T., Yoshino A., J. Power Sources, 97 - 98 (2001), 430.

[4] Fisher C.A.J., Hart Prieto V.M., SAiful IsLAM M., Chem. Mater., 20 (2008), 5907.

[5] Bhuvaneswari D., Gangulibabu, Doh C.H., Kalaiselvi N., Int. J. Electrochem. Sc., 6 (2011), 3714.

[6] Koleva V., Stoyanova R., Zhecheva E., Eur. J. Inorg. Chem., 1 (2010), 127.

[7] Minakshi M., Singh P., Appadoo D., Martin D.E., Electrochim. Acta, 56 (2011), 4356.

[8] Yang G., Ni H., LiU H., Gao P., Ji H., Roy S., Pinto J., Jiang X., J. Power Sources, 196 (2011), 4747.

[9] Shanmukaraj D., Murugan R., Ionics, 10 (2004), 88.

[10] Julien C., Camacho Lopez M.A., Mohan T., Chitra S., Kalyani P., Gopukumar S., Solid State Ionics, 135 (2000), 241.

[11] Padhi A.K., Nanjundaswamy K.S., GoodeNOUGH J.B., J. Electrochem. Soc., 144 (1997), 1188.

[12] Wolfenstine J., Allen J., J. Power Sources, 142 (2005) 389.

[13] Muralidharan P., Venkateswarlu M., SatyaNARAYANA N., Solid State Ionics, 166 (2004), 27.

[14] Su J., Wei B.Q., Rong J.P., Yin W.Y., Ye Z.X., Tian X.Q., Ren L., CaO M.H., Hu C.W., J. Solid State Chem., 184 (2011), 2909.

[15] Broussely M., Biensan P., Simon B., Electrochim. Acta, 45 (1999), 3.

[16] Chen J., Vacchio M.J., Wang S., Chernova N., ZaValiu P.Y., Wittingham M.S., Solid State Ionics, 178 (2008), 1676

[17] Sanusi A., NaVaratnam S., Basirun W.J., Malays. J. Anal. Sci., 18 (2014), 522.

[18] Gangulibabu, Bhuvaneswari D., Kalaiselvi N., Jayaprakash N., Periasamy P., J. Sol-Gel Sci. Techn., 49 (2009), 137.

[19] Qinga R., Yang M.C., Meng Y.S., Sigmund W., Electrochim. Acta, 108 (2013), 827.

[20] Takahashi M., Tobishima S., Takei K., SAKURAI Y., J. Power Sources, 97-98 (2001), 508.
[21] Kim S.W., Kim J., Gwon H., Kang K., J. Electrochem. Soc., 156 (2009), A635.

[22] Iriyama Y., Kako T., Yada C., Abe T., Ogumi Z. Solid State Ionics, 176 (2005), 2395.

[23] Muraliganth T., Manthiram A., J. Phys. Chem. $C, 114$ (2010), 15530.

[24] Amine K., Yasuda H., Yamachi M., Solid State Lett., 3 (2000), 178.

[25] Ait SAlah A., JozWiak P., GarbarczyK J., Benkhouja K., Zaghib K., Gendron F., Julien C.M., J. Power Sources, 140 (2005), 370.

[26] Rouier A., NAZRi G.A., Julian C., Ionics, 3 (1997), 170.

[27] MacDonald J. R., Impedance Spectroscopy, Wiley, New York, 1987.

[28] Irvine J.T.C., Sinclair D.C., West A.R., Adv Mater., 2 (1990) 138-140.

[29] Ellis B., Herle P.S., RHO Y.H., NAZAR L.F., DuNLAP R., PERRY L.K., RYAN D.H., Faraday Discuss., 134 (2007) 119.

[30] Wilk P., Marzec J., Molenda J., Solid State Ionics, 157 (2003), 109.

[31] Bohnke O., Emery J., Fourquet J.L., Solid State Ionics, 158 (2003), 119.

[32] Rissouli K., Benkhouja K., Ramos-Barrado J.R., Julien C., Mater. Sci. Eng. B-Adv., 98 (2003), 185.

[33] Ben Bechir M., Ben Rhaiem A., Guidara K., $B$. Mater. Sci., 37 (2014)1.

[34] Julien C.M., Mauger A., Zaghib K., VeilLETTE R., GROUlT H., Ionics, 18 (2012)625.

[35] Aranda M.A.G., BRuQue S., RAmos BARrado J.R., ATTFIELD J.P., Solid State Ionics, 63 - 65 (1993), 407.

[36] Prabhu M., Selvasekarapandian S., Kulkarni A.R., Karthikeyan S., Sanjeeviraja C., T. Nonferr. Metal. Soc., 22 (2012), 342.

[37] Ben Rhaiem A., Hlel F., Guidara K., GarGOURI M., J. Alloy. Compd., 485 (2009), 718.

[38] Jin B., Gu H.B., Solid State Ionics, 178 (2008), 1907.

[39] Bharadwaja S.S.N., Krupanidhi S.B., Thin Solid Films, 391 (2001), 126

[40] Orliukas A., Dindune A., Kanepe Z., Solid State Ionics, 157 (2003), 177.

[41] Prabu M., Selvasekarapandian S., Kulkarni A.R., Karthikeyan S., HiRANKUMAR G., SANJEEVIRAJA C., Ionics, 17 (2011), 201.

[42] Moynihan C.T., Bosech L.P., Laberge N.L., Phys. Chem. Glass-B, 14 (1973), 122.

[43] Selwin Joseyphus R., Viswanathan E., Justin Dhanaraj C., Joseph J., J. K. Saudi Univ. Sc., 24 (2012), 233.

Received 2016-03-31 Accepted 2016-11-28 